\title{
Crystalline Ceramic Waste Forms: Comparison of Reference Process for Ceramic Waste Form Fabrication
}

\section{Fuel Cycle Research \& Development}

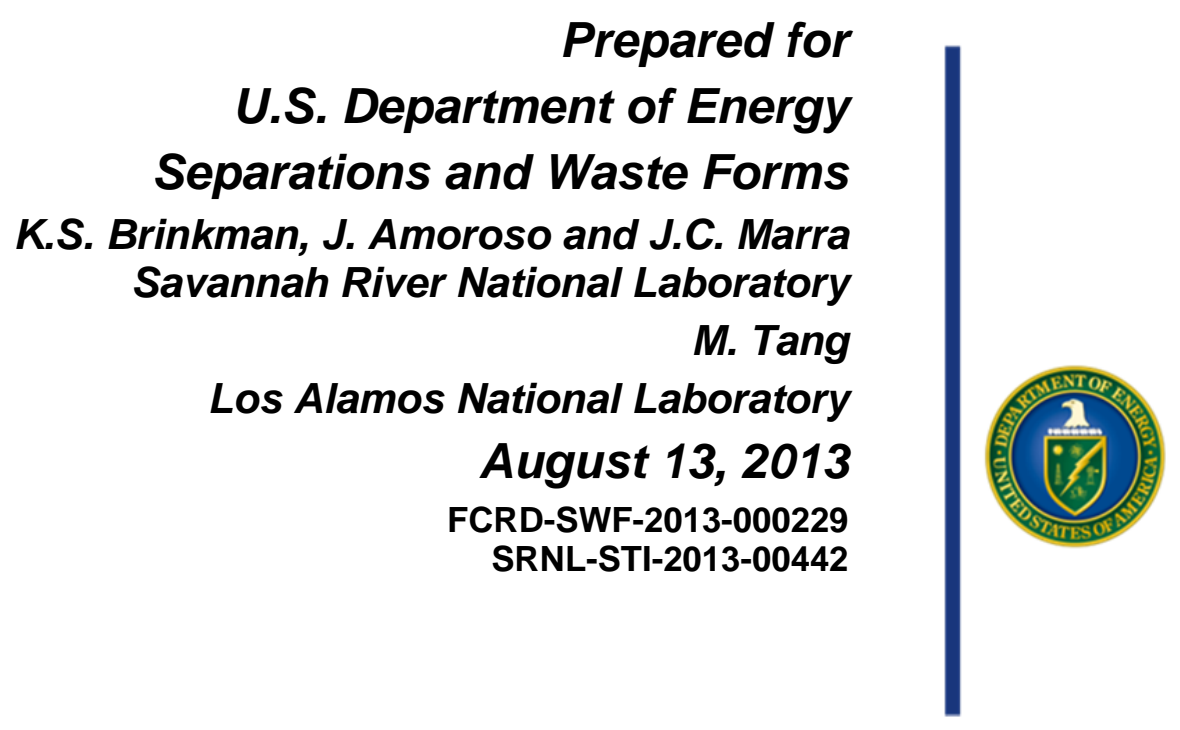




\section{DISCLAIMER}

This information was prepared as an account of work sponsored by an agency of the U.S. Government. Neither the U.S. Government nor any agency thereof, nor any of their employees, makes any warranty, expressed or implied, or assumes any legal liability or responsibility for the accuracy, completeness, or usefulness, of any information, apparatus, product, or process disclosed, or represents that its use would not infringe privately owned rights. References herein to any specific commercial product, process, or service by trade name, trade mark, manufacturer, or otherwise, does not necessarily constitute or imply its endorsement, recommendation, or favoring by the U.S. Government or any agency thereof. The views and opinions of authors expressed herein do not necessarily state or reflect those of the U.S. Government or any agency thereof. 


\section{SUMMARY}

The research conducted in this work package is aimed at taking advantage of the long term thermodynamic stability of crystalline ceramics to create more durable waste forms (as compared to high level waste glass) in order to reduce the reliance on engineered and natural barrier systems. Durable ceramic waste forms that incorporate a wide range of radionuclides have the potential to broaden the available disposal options and to lower the storage and disposal costs associated with advanced fuel cycles. Assemblages of several titanate phases have been successfully demonstrated to incorporate radioactive waste elements, and the multiphase nature of these materials allows them to accommodate variation in the waste composition. Recent work has shown that they can be produced from a melting and crystallization process. The objective of this report is to explore the phase formation and microstructural differences between lab scale melt processing in varying gas environments with alternative densification processes such as Hot Pressing (HP) and Spark Plasma Sintering (SPS).

The waste stream used as the basis for the development and testing is a simulant derived from a combination of the projected Cs/Sr separated stream, the Trivalent Actinide - Lanthanide Separation by Phosphorous reagent Extraction from Aqueous Komplexes (TALSPEAK) waste stream consisting of lanthanide fission products, the transition metal fission product waste stream resulting from the transuranic extraction (TRUEX) process, and a high molybdenum concentration with relatively low noble metal concentrations.

Melt processing as well as solid state sintering routes SPS and HP demonstrated the formation of the targeted phases; however differences in microstructure and elemental partitioning were observed. In SPS and HP samples, hollandite, pervoskite/pyrochlore, zirconolite, metallic alloy and $\mathrm{TiO}_{2}$ and $\mathrm{Al}_{2} \mathrm{O}_{3}$ were observed distributed in a network of fine grains with small residual pores. The titanate phases that incorporate $\mathrm{M}^{+3}$ rare earth elements were observed to be distinct phases (ex. $\mathrm{Nd}_{2} \mathrm{Ti}_{2} \mathrm{O}_{7}$ ) with less degree of substitution as compared to the more homogeneous melt processed samples where a high degree of substitution and variation of composition within grains was observed. Liquid phase sintering was enhanced in reducing gas environments and resulted in large (10-200 microns) irregular shaped grains along with large voids associated with the melt process; SPS and HP samples exhibited finer grain size with smaller voids. Metallic alloys were observed in the bulk of the sample for SPS and HP samples, but were found at the bottom of the crucible in melt processed trials. These results indicate that for a first melter trial, the targeted phases can be formed in air by utilizing $\mathrm{Ti} / \mathrm{TiO}_{2}$ additives which aid phase formation and improve the electrical conductivity. Ultimately, a melter run in reducing gas environments would be beneficial to study differences in phase formation and elemental partitioning. 


\section{CONTENTS}

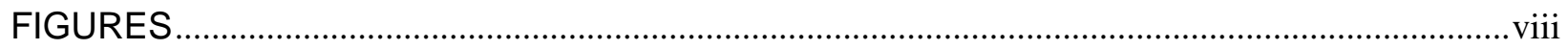

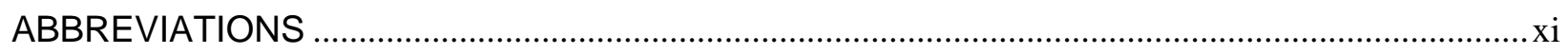

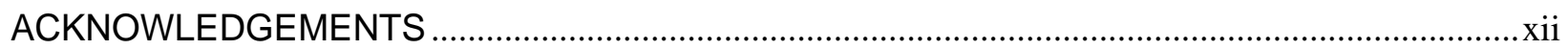

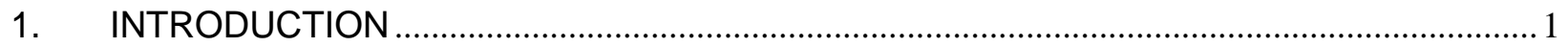

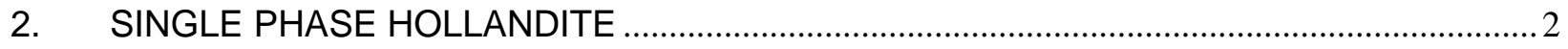

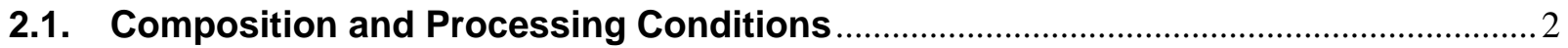

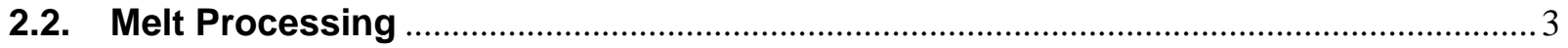

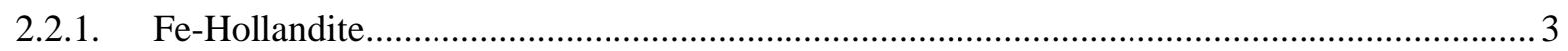

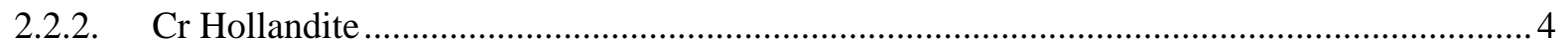

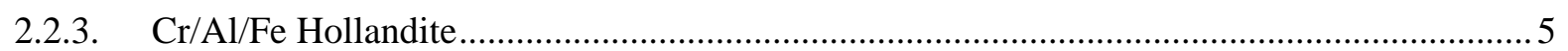

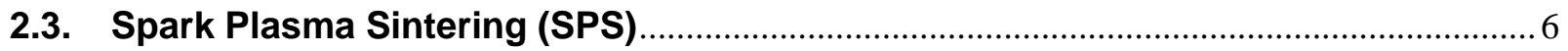

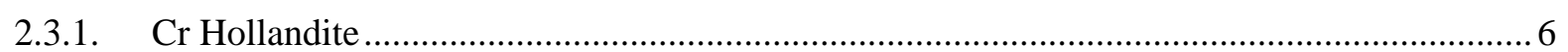

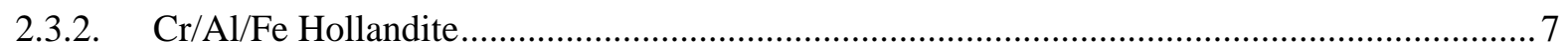

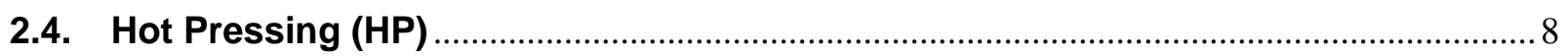

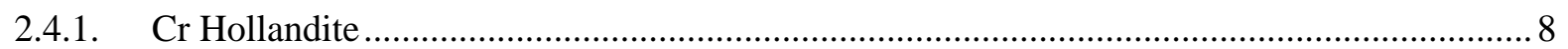

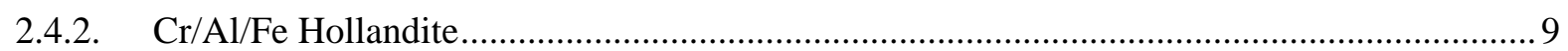

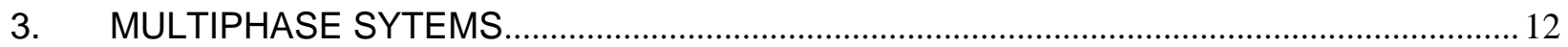

3.1. Composition Development and Processing Conditions........................................... 12

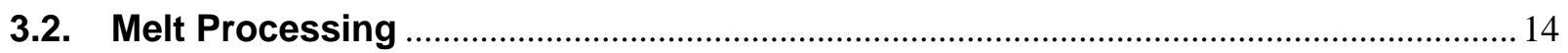

3.2.1. Cr- Hollandite Multiphase Waste form ............................................................................ 14

3.2.2. $\mathrm{Cr} / \mathrm{Al} / \mathrm{Fe}$ Hollandite Multiphase Waste form ................................................................... 15

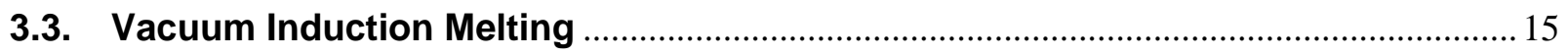

3.3.1. Cr-Hollandite Multiphase Waste Form ........................................................................... 16

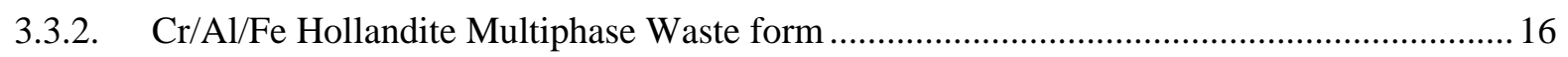

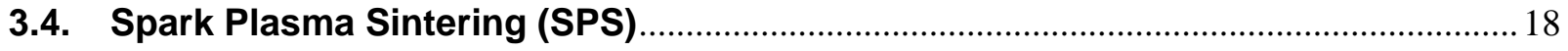

3.4.1. Cr-Hollandite Multiphase Waste Form ............................................................................. 18

3.4.2. $\mathrm{Cr} / \mathrm{Al} / \mathrm{Fe}$ Hollandite Multiphase Waste form ................................................................ 19

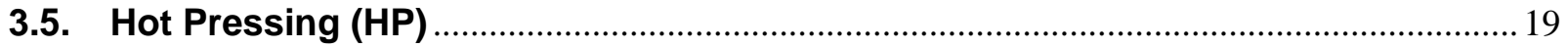

3.5.1. Cr-Hollandite Multiphase Waste Form ............................................................................ 20

3.5.2. $\mathrm{Cr} / \mathrm{Al} / \mathrm{Fe}$ Hollandite Multiphase Waste form .................................................................... 20

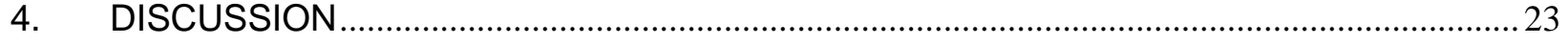

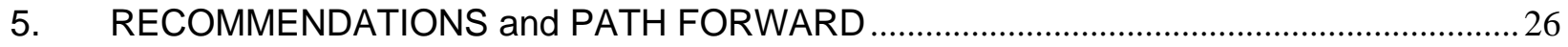

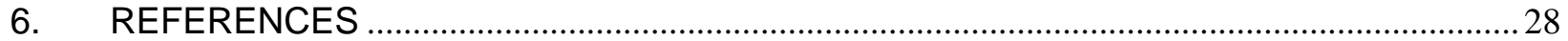




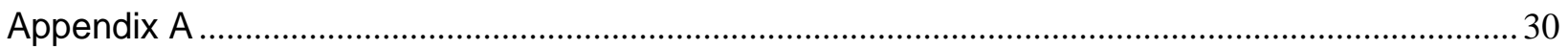




\section{FIGURES}

Figure 2-1. Fe-Hollandite Fabricated by Melting and Crystallizing in $1 \% \mathrm{H}_{2}$ balance Argon without

$\mathrm{Ti} / \mathrm{TiO}_{2}$ buffer Backscattered Electron Micrograph

Figure 2-2. Cr-Hollandite Fabricated by Melting and Crystallizing in $1 \% \mathrm{H}_{2}$ balance Argon without

$\mathrm{Ti} / \mathrm{TiO}_{2}$ buffer Backscattered Electron Micrograph

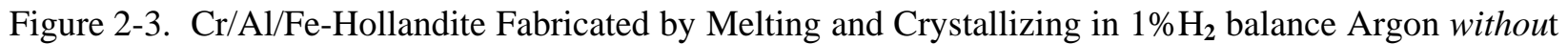

$\mathrm{Ti} / \mathrm{TiO}_{2}$ buffer Backscattered Electron Micrograph

Figure 2-4. Cr-Hollandite Fabricated by SPS with $\mathrm{Ti} / \mathrm{TiO}_{2}$ buffer at $1240^{\circ} \mathrm{C}$ Backscattered Electron Micrograph

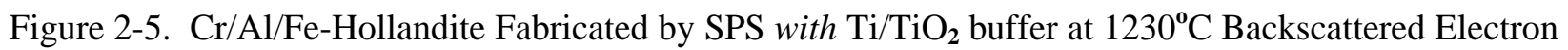
Micrograph ... 8

Figure 2-6. Cr-Hollandite with $\mathrm{Ti} / \mathrm{TiO}_{2}$ buffer Fabricated by $\mathrm{HP}$ at $40 \mathrm{MPa}$ under $\mathrm{N}_{2}$ gas at $1200^{\circ} \mathrm{C}$ for 2 hours- Backscattered Electron Micrograph

Figure 2-7. $\mathrm{Cr} / \mathrm{Al} / \mathrm{Fe}-\mathrm{Hollandite}$ with $\mathrm{Ti} / \mathrm{TiO}_{2}$ buffer Fabricated by $\mathrm{HP}$ at $40 \mathrm{MPa}$ under $\mathrm{N}_{2}$ gas at $1200^{\circ} \mathrm{C}$ for 2 hours- Backscattered Electron Micrograph. 10

Figure 3-1. Cr-Hollandite Multiphase Waste Form (Cr-MPB1R-Ti) Fabricated Melt Processing $1500^{\circ} \mathrm{C}$ with $\mathrm{Ti} / \mathrm{TiO}_{2}$ buffer additions in $1 \% \mathrm{H}_{2}$ /balance Argon atmosphere- Backscattered Electron Micrograph ... 14

Figure 3-2. $\mathrm{Cr} / \mathrm{Al} / \mathrm{Fe}-\mathrm{Hollandite}$ Fabricated Melt Processing at $1500^{\circ} \mathrm{C}$ with $\mathrm{Ti} / \mathrm{TiO}_{2}$ buffer additions in $1 \% \mathrm{H}_{2} /$ balance Argon atmosphere Backscattered Electron Micrograph 15

Figure 3-3. Cr-Hollandite Fabricated by Vacuum Induction Melting at $1500^{\circ} \mathrm{C}$ with $\mathrm{Ti} / \mathrm{TiO}_{2}$ bufferBackscattered Electron Micrograph 16

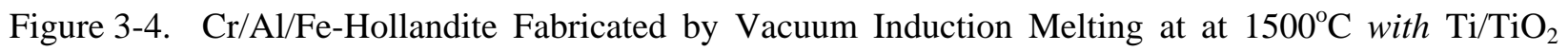
buffer -Backscattered Electron Micrograph

Figure 3-5. $\mathrm{Cr}$-Hollandite Fabricated by SPS with $\mathrm{Ti} / \mathrm{TiO}_{2}$ buffer $1232^{\circ} \mathrm{C}$ - Backscattered Electron Micrograph 18

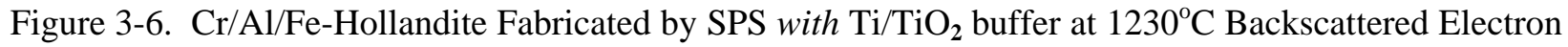
Micrograph 19

Figure 3-7. Cr-Hollandite Fabricated by $\mathrm{HP} 1200^{\circ} \mathrm{C}$ with $\mathrm{Ti} / \mathrm{TiO}_{2}$ buffer- Backscattered Electron Micrograph 20

Figure 3-8. $\mathrm{Cr} / \mathrm{Al} / \mathrm{Fe}-\mathrm{Hollandite}$ Fabricated by $\mathrm{HP} 1200^{\circ} \mathrm{C}$ with $\mathrm{Ti} / \mathrm{TiO}_{2}$ buffer Backscattered Electron Micrograph

Figure 4-1. Single Phase Hollandite $\mathrm{Cr} / \mathrm{Al} / \mathrm{Fe}$ with $\mathrm{Ti} / \mathrm{TiO}_{2}$ Processing Comparison- Backscattered Electron Micrograph. (Air=Melting $1500^{\circ} \mathrm{C}$ in Air, $1 \% \mathrm{H}_{2}=$ Melting $1500^{\circ} \mathrm{C}$ in $1 \% \mathrm{H}_{2}$ balance Argon gas, SPS $=\mathrm{SPS}$ at $1230^{\circ} \mathrm{C}, \mathrm{HP}=\mathrm{HP}$ at $1200^{\circ} \mathrm{C}$ at $40 \mathrm{MPa}$ ).

Figure 4-2. Multiphase Waste Form $\mathrm{Cr} / \mathrm{Al} / \mathrm{Fe}$ Hollandite with $\mathrm{Ti} / \mathrm{TiO}_{2}$ Processing ComparisonBackscattered Electron Micrograph 


\section{TABLES}

Table 2-1. Fe-Hollandite Fabricated by Melting and Crystallizing in $1 \% \mathrm{H}_{2}$ without $\mathrm{Ti} / \mathrm{TiO}_{2}$ buffer Fabricated by Melting and Crystallizing -Summary of Elements and Crystalline Phases ( ${ }^{*}$ Crystalline phases determined from X-ray Diffraction XRD measurements and Energy Dispersive X-ray Spectroscopy EDAX elemental analysis).

Table 2-2. Cr-Hollandite Fabricated by Melting and Crystallizing in $1 \% \mathrm{H}_{2}$ without $\mathrm{Ti} / \mathrm{TiO}_{2}$ buffer Fabricated by Melting and Crystallizing -Summary of Elements and Crystalline Phases ( ${ }^{*}$ Crystalline phases determined from XRD measurements and EDAX elemental analysis)

Table 2-3. $\mathrm{Cr} / \mathrm{Al} / \mathrm{Fe}-H o l l a n d i t e ~ F a b r i c a t e d ~ b y ~ M e l t i n g ~ a n d ~ C r y s t a l l i z i n g ~ i n ~ 1 \% \mathrm{H}_{2}$ without $\mathrm{Ti} / \mathrm{TiO}_{2}$ buffer Fabricated by Melting and Crystallizing -Summary of Elements and Crystalline Phases $\left({ }^{*}\right.$ Crystalline phases determined from XRD measurements and EDAX elemental analysis).....

Table 2-4. Cr-Hollandite Fabricated by SPS with $\mathrm{Ti} / \mathrm{TiO}_{2}$ at $1240^{\circ} \mathrm{C}$-Summary of Elements and Crystalline Phases (*Crystalline phases determined from XRD measurements and EDAX elemental analysis).....

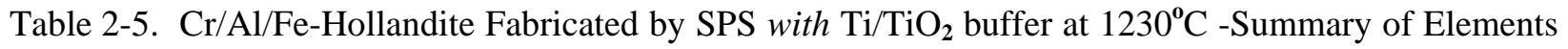
and Crystalline Phases ( ${ }^{*}$ Crystalline phases determined from XRD measurements and EDAX elemental analysis)

Table 2-6. $\mathrm{Cr}$-Hollandite with $\mathrm{Ti} / \mathrm{TiO}_{2}$ buffer Fabricated by $\mathrm{HP}$ at $40 \mathrm{MPa}$ under $\mathrm{N}_{2}$ gas at $1200^{\circ} \mathrm{C}$ for 2 hours -Summary of Elements and Crystalline Phases (*Crystalline phases determined from XRD measurements and EDAX elemental analysis)

Table 2-7. $\mathrm{Cr} / \mathrm{Al} / \mathrm{Fe}-\mathrm{Hollandite}$ with $\mathrm{Ti} / \mathrm{TiO}_{2}$ buffer Fabricated $\mathrm{HP}$ at $40 \mathrm{MPa}$ under $\mathrm{N}_{2}$ gas at $1200^{\circ} \mathrm{C}$ for 2 hours -Summary of Elements and Crystalline Phases $\left({ }^{*}\right.$ Crystalline phases determined from XRD measurements and EDAX elemental analysis) 10

Table 2-8. Single Phase Hollandite Characterization Summary .11

Table 3-1. Ceramic Waste Form Compositions for SRNL Multiphase Melt Samples compared to SYNROC-C[11]; weight percent of oxide component.

Table 3-2. Chemical Composition (Batch Sheets) of SRNL Multiphase Melt Samples compared to SYNROC-C[11]; weight percent of oxide component. 13

Table 3-3. Cr-Hollandite Multiphase Waste Form (Cr-MPB1R-Ti) Fabricated Melt Processing $1500^{\circ} \mathrm{C}$ with $\mathrm{Ti} / \mathrm{TiO}_{2}$ buffer additions in $1 \% \mathrm{H}_{2}$ /balance Argon atmosphere- Summary of Elements and Crystalline Phases ( ${ }^{*}$ Crystalline phases determined from XRD measurements and EDAX elemental analysis)......

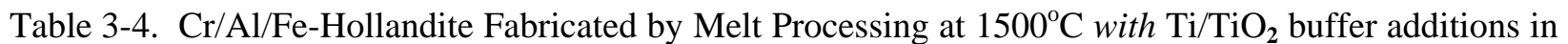
$1 \% \mathrm{H}_{2}$ /balance Argon atmosphere -Summary of Elements and Crystalline Phases ( ${ }^{*}$ Crystalline phases determined from XRD measurements and EDAX elemental analysis)...... 15

Table 3-5. Cr-Hollandite Fabricated by Vacuum Induction Melting at $1500^{\circ} \mathrm{C}$ with $\mathrm{Ti} / \mathrm{TiO}_{2}$ buffer Summary of Elements and Crystalline Phases (*Crystalline phases determined from XRD measurements and EDAX elemental analysis) 


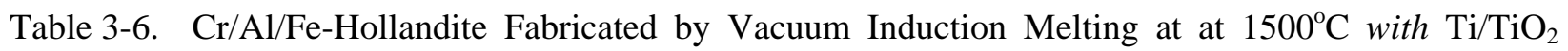
buffer -Summary of Elements and Crystalline Phases ( ${ }^{*}$ Crystalline phases determined from XRD measurements and EDAX elemental analysis)

Table 3-7. Cr-Hollandite Fabricated by SPS with $\mathrm{Ti} / \mathrm{TiO}_{2}$ buffer at $1232^{\circ} \mathrm{C}$-Summary of Elements and Crystalline Phases ( ${ }^{*}$ Crystalline phases determined from XRD measurements and EDAX elemental analysis)..... 18

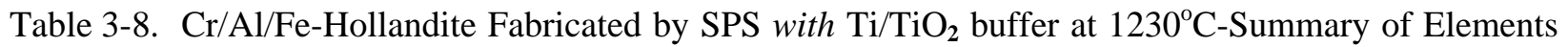
and Crystalline Phases (*Crystalline phases determined from XRD measurements and EDAX elemental analysis)

Table 3-9. Cr-Hollandite Fabricated by $\mathrm{HP} 1200^{\circ} \mathrm{C}$ with $\mathrm{Ti} / \mathrm{TiO}_{2}$ buffer -Summary of Elements and Crystalline Phases ( ${ }^{*}$ Crystalline phases determined from XRD measurements and EDAX elemental analysis) 20

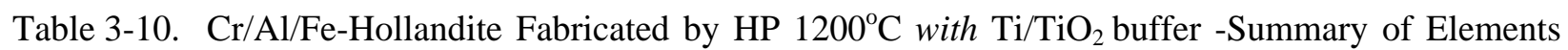
and Crystalline Phases (*Crystalline phases determined from XRD measurements and EDAX

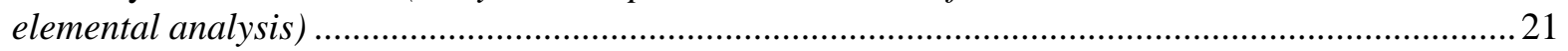

Table 3-11. Multiphase Characterization Summary ............................................................................ 22

Table 4-1. Single Phase Hollandite $\mathrm{Cr} / \mathrm{Al} / \mathrm{Fe}$ with $\mathrm{Ti} / \mathrm{TiO}_{2}$ Processing Comparison -Summary of Elements and Crystalline Phases (*Crystalline phases determined from XRD measurements and EDAX elemental analysis).....

Table 4-2. Multiphase Waste Form $\mathrm{Cr} / \mathrm{Al} / \mathrm{Fe}$ Hollandite with $\mathrm{Ti} / \mathrm{TiO}_{2}$ Processing Comparison -Summary of Elements and Crystalline Phases ( ${ }^{*}$ Crystalline phases determined from XRD measurements and EDAX elemental analysis).... 26 


\section{ABBREVIATIONS}

CCIM Cold Crucible Induction Melter

DOE Department of Energy

EDAX Energy Dispersive Spectroscopy

FCR\&D Fuel Cycle Research and Development

HLW High Level Waste

HP Hot Pressing (uniaxial)

HIP Hot Isostatic Pressing

PUREX Plutonium, Uranium, Extraction Processes

RedOx Reduction/Oxidation

REE Rare Earth Element

SEM Scanning Electron Microscopy

SRNL Savannah River National Laboratory

SYNROC Titanium based ceramic substance that can incorporate nuclear waste

TALSPEAK Trivalent Actinide - Lanthanide Separation by Phosphorous reagent

TRUEX $\quad$ Transuranic Extraction

XANES X-ray Absorption Near Edge Structure

XRD X-ray Diffraction

XPS X-ray Photoelectron Spectroscopy 


\section{ACKNOWLEDGEMENTS}

The authors would like to thank Henry Ajo, David Best, David Missimer, Elise Fox, Phyllis Workman, Pat Simmons, Whitney Riley, Mark Jones, and Curtis Johnson of SRNL for their assistance with sample preparation and characterization. The Hot Pressing and Spark Plasma Sintering samples analyzed in this work were fabricated at Clemson University by Prof. Jian He under the subcontract "SCN0010 Alternative Sintering of Waste Forms.”

\section{Government License Notice}

This work was prepared under an agreement with and funded by the U.S. Government. Neither the U. S. Government or its employees, nor any of its contractors, subcontractors or their employees, makes any express or implied: 1 . warranty or assumes any legal liability for the accuracy, completeness, or for the use or results of such use of any information, product, or process disclosed; or 2. representation that such use or results of such use would not infringe privately owned rights; or 3 . endorsement or recommendation of any specifically identified commercial product, process, or service. Any views and opinions of authors expressed in this work do not necessarily state or reflect those of the United States Government, or its contractors, or subcontractors.

This document has been created by Savannah River Nuclear Solutions, LLC, Operator of Savannah River National Laboratory under Contract No. DE-AC09-08SR22470. The U.S. Government retains for itself, and others acting on its behalf, a paid-up nonexclusive, irrevocable worldwide license in said article to reproduce, prepare derivative works, distribute copies to the public, and perform publicly and display publicly, by or on behalf of the Government.

This work was supported by the U.S. Department of Energy, Office of Nuclear Energy, under Contract DE-AC02-06CH11357. 


\section{INTRODUCTION}

Efforts being conducted by the United States Department of Energy (DOE) under the Fuel Cycle Research and Development (FCR\&D) program are aimed at making potential U.S. fuel cycle options more effective by the development of next generation waste management technologies.[1] One envisioned fuel reprocessing technology would separate the fuel into several fractions, thus, partitioning the waste into groups with common chemistry. Ceramic (or crystalline) waste forms incorporate the radionuclides in the waste as part of the crystal structure.[2] As such, ceramic forms are tailored to create certain minerals (i.e. unique crystalline structures) that will host the radionuclides by binding them in their specific crystalline network. Tailoring of a ceramic waste form is based on the knowledge that there are many naturally produced minerals containing radioactive and non-radioactive species very similar to the radionuclides of concern in wastes from fuel reprocessing. The research conducted in this work package is aimed at taking advantage of the long term thermodynamic stability of crystalline ceramics to create more durable waste forms (as compared to high level waste (HLW) glass) in order to reduce the reliance on engineered and natural barrier systems. Durable ceramic waste forms that incorporate a wide range of radionuclides have the potential to broaden the available disposal options and to lower the storage and disposal costs associated with advanced fuel cycles.

Titanate ceramics have been thoroughly studied for use in immobilizing nuclear wastes (e.g., the synthetic rock, or "SYNROC" family) due to their natural resistance to leaching in water.[2, 3] Assemblages of several titanate phases have been successfully demonstrated to incorporate radioactive waste elements, and the multiphase nature of these materials allows them to accommodate variation in the waste composition.[4] While these materials are typically densified via hot isostatic pressing (HIP), recent work has shown that they can also be produced from a melt. For example, demonstrations have been completed using the Cold Crucible Induction Melter (CCIM) technology to produce several crystalline ceramic waste forms, including murataite-rich ceramics,[5] zirconolite/pyrochlore ceramics,[6] Synroc-C (zirconolite, hollandite, perovskite),[7] aluminotitanate ceramics, and zirconia.[8] This production route is advantageous since melters are already in use for defense HLW vitrification in several countries, and melter technology greatly reduces the potential for airborne contamination as compared to powder handling operations associated with hot isostatic pressing.

Previous reports completed in FY12 summarized the reference ceramic compositions and the results of initial melt processing for several targeted waste streams of interest to the FCR\&D program[9, 10]. In agreement with previous attempts at melt processing Mo containing SYNROC type ceramics in oxidizing environments, the Savannah River National Laboratory (SRNL) designed crystalline ceramics melted in air showed evidence of non-durable molybdate phase formation[11]. Several strategies to address this issue were suggested in the FY12 reports including i) tailoring the hollandite stoichiometry to make Cs incorporation more favorable, ii) the addition of solid state reducing agents such as Ti metal to the batch, and iii) melt processing in reducing gas environments $\left(1 \% \mathrm{H}_{2}\right.$ balance Argon). The current report on FY13 work summarizes the results of these experiments aimed at varying the composition and reducing conditions in lab scale melts. In addition, this report presents an initial comparison of various reference processes for waste form fabrication including melt processing, hot pressing and spark plasma sintering with a focus on phase formation, microstructure and elemental partitioning. A premise of this work is that if the targeted crystalline phases are formed, the resulting durability will be comparable to SYNROC performance in the literature. Durability and leaching studies are not addressed in this report. 


\section{SINGLE PHASE HOLLANDITE}

Cs is one of the more problematic fission product radionuclides to immobilize due to its high volatility at elevated temperatures, ability to form water soluble compounds, and its mobility in many host materials. A hollandite-type crystal structures appears to be a good candidates for Cs immobilization compared to other proposed silicate or phosphate ceramics which are difficult to fabricate as single phase wasteforms with high densities, or to nuclear glasses in which the alkaline elements are the most mobile waste species in aqueous environments. There are natural analogues of hollandite including ankagite, found in dolomitic marble in the Apuan Alps in Tuscany, Italy.[12] There has been limited work on the melt processing of single phase hollandite materials. Existing literature has focused Cs-rich waste targeted in dual phase hollandite/rutile mixtures fabricated via melt processing in air.[13] Hollandite formation based on dopants of $\mathrm{Zn}$, Co, or Ni were successfully demonstrated in binary systems by melt processing in air. However, it is believed that reducing environments will be required to avoid molybdate (Cs-Mo) phase formation in the multiphase FCR\&D waste forms of interest. This work has focused on tailoring the compositions and conditions that enable Cs incorporation into the hollandite phase under reducing conditions. The following section describes the choice of composition and processing conditions for the hollandite phase.

\subsection{Composition and Processing Conditions}

Although it is difficult to form a $\left(\mathrm{Ba}_{\mathrm{x}} \mathrm{Cs}_{\mathrm{y}}\right)(\mathrm{Ti}, \mathrm{Al})^{+3}{ }_{2 \mathrm{x}+\mathrm{y}}\left(\mathrm{Ti}^{+4}{ }_{8-2 \mathrm{x}-\mathrm{y}}\right) \mathrm{O}_{16}$ single phase hollandite in oxidizing atmospheres, other $\mathrm{M}^{+3}$ elements such as $\mathrm{Fe}^{3+}$ can be substituted into the $\left(\mathrm{Ba}_{\mathrm{x}} \mathrm{Cs}_{\mathrm{y}}\right)(\mathrm{Ti}, \mathrm{Al})^{+3}{ }_{2 \mathrm{x}+\mathrm{y}}\left(\mathrm{Ti}^{+4}{ }_{8-2 \mathrm{x}-\mathrm{y}}\right) \mathrm{O}_{16}$ phase targeting $\mathrm{Ba}_{1.0} \mathrm{Cs}_{0.28} \mathrm{Al}_{1.46} \mathrm{Fe}_{0.82} \mathrm{Ti}_{5.72} \mathrm{O}_{16}$ which has been shown to form a stable single phase compound. Recently, single phase hollandite materials containing mixtures of divalent and trivalent cations have been fabricated by solution mixtures and oxide routes based on the general formula $\left(\mathrm{Ba}_{\mathrm{x}} \mathrm{Cs}_{\mathrm{y}}\right)\left(\mathrm{M}^{+3}{ }_{\mathrm{z}} \mathrm{Ti}^{+4}{ }_{8-\mathrm{z}}\right) \mathrm{O}_{16}$ with $\mathrm{M}=\mathrm{Mn}^{+3}, \mathrm{Fe}^{+3}, \mathrm{Ga}^{+3}, \mathrm{Cr}^{+3}, \mathrm{Sc}^{+3}, \mathrm{Ti}^{+3}, \mathrm{Ni}^{+2}, \mathrm{Co}^{+2}, \mathrm{Zn}^{+2}$, and $\mathrm{Mg}^{+2}$ where $\mathrm{z}=2 \mathrm{x}+\mathrm{y}$ for trivalent cations and $\mathrm{z}=\mathrm{x}+\mathrm{y} / 2$ for divalent cations for charge compensation.[1417] In general, many of those trivalent and divalent cations were effective in promoting Cs incorporation into the hollandite, but also promoted secondary phase formation. Dopants which have the atomic radius appropriate for the $\mathrm{M}^{+3}$ site in the hollandite are not found in the anticipated waste streams. However, taking into consideration the corrosion products and other additives from the separations processes results in appreciable concentrations of $\mathrm{Cr}_{2} \mathrm{O}_{3}$ and/or $\mathrm{Fe}_{2} \mathrm{O}_{3}(\sim 1-10 \mathrm{wt} \%)$ arising from Purex or JW-A processing contamination[18, 19]. The presence of $\mathrm{Fe}^{+3}$ (coexisting with $\mathrm{Al}^{+3}$ ) in the $\mathrm{B}$ site of the structure facilitated Cs incorporation via calcining at $1000^{\circ} \mathrm{C}$ and air sintering at $1200^{\circ} \mathrm{C}$. In addition, iron oxide and chromium oxide additions may improve the densification and melting properties due to the lower melting point as compared to $\mathrm{Al}_{2} \mathrm{O}_{3}$ rich compositions.

Cr was identified as a potential additive because it has consistently resulted in single phase hollandite formation in air throughout the literature. There is very little data published concerning the melt processing or fabrication of the $\mathrm{Cr}$ analogue in varying redox conditions. The Al-Fe containing hollandite has been widely studied, however this work developed a new $\mathrm{Cr}-\mathrm{Al}-\mathrm{Fe}$ composition to exploit the $\mathrm{Cr}$ ionic radius (less than $\mathrm{Fe}^{+3}$ but greater than $\mathrm{Al}^{+3}$ ) which is expected to promote single phase formation while maximizing Cs incorporation. A pure Fe analogue, expected to be multiphase and exhibit poor durability, was included as a baseline for the comparison of results. The three compositions studied in this work were: $\mathrm{Ba}_{1.0} \mathrm{Cs}_{0.3} \mathrm{Fe}_{2.3} \mathrm{Ti}_{5.7} \mathrm{O}_{16}$ - referred to as Fe-Hol, $\mathrm{Ba}_{1.0} \mathrm{Cs}_{0.3} \mathrm{Cr}_{2.3} \mathrm{Ti}_{5.7} \mathrm{O}_{16}$ - referred to as Cr$\mathrm{Hol}$, and $\mathrm{Ba}_{1.0} \mathrm{Cs}_{0.3} \mathrm{Cr}_{1.0} \mathrm{Al}_{0.3} \mathrm{Fe}_{1.0} \mathrm{Ti}_{5.7} \mathrm{O}_{16}$ - referred to as $\mathrm{Cr} / \mathrm{Al} / \mathrm{Fe}-\mathrm{Hol}$.

The batch preparation of the three compositions was as follows: stoichiometric amounts of reagent-grade oxide and carbonate powders were mixed to make $100 \mathrm{~g}$ of each hollandite material. These powders were 
combined in a 500ml plastic bottle with zirconia milling media, filled 2/3 full with deionized water, and agitated in a tumbler mixer for 1 hour. The resulting slurry was poured into a separate pan along with additional rinse water used to collect any batch material remaining on the milling media and bottles. Each pan was transferred to an oven where the slurry was dried for several days at $90^{\circ} \mathrm{C}$. The dried material was bagged and used as feed stock for synthesis experiments. In addition to compositional variants, all samples were processed with excess $\mathrm{Ti}$ metal and $\mathrm{TiO}_{2}$ (referred to in this text as $\mathrm{Ti} / \mathrm{TiO}_{2}$ buffer). The $\mathrm{Ti}$ metal was added $-<230$ mesh, $\sim 2.0$ wt. \% - to control the RedOx state during processing and in effect, phase formation. $\mathrm{TiO}_{2}$ was added $-\sim 6.5 \mathrm{wt}$. \% - to buffer the reducing effects of the Ti metal on $\mathrm{TiO}_{2}$. [10] In this fashion, a combination of gas phase environment and solid state reducing agents were used to vary the RedOx conditions using different processing techniques: i) melt processing of compositions with and without $\mathrm{Ti} / \mathrm{TiO}_{2}$ buffer in air and $1 \% \mathrm{H}_{2}$ /balance Argon gas environments, ii) spark plasma sintering with a $\mathrm{Ti} / \mathrm{TiO}_{2}$ buffer in $\mathrm{N}_{2}$ gas at varying temperatures and iii) hot press with and without $\mathrm{Ti} / \mathrm{TiO}_{2}$ buffer in $\mathrm{N}_{2}$ gas at varying temperatures.

The microstructures of select samples are presented along with a table indicating the elemental composition and crystalline phases observed in each section. A summary of the entirety of results on single phase hollandite across composition and processing method and reducing conditions is summarized in a table at the end of Section 2.4.

\subsection{Melt Processing}

Approximately 20g samples of feed stock were loosely placed into a covered alumina crucible. The samples were heated in air and in $1 \% \mathrm{H}_{2}$ (balance Argon) reducing atmosphere. Samples were heated at approximately $15^{\circ} \mathrm{C} / \mathrm{min}$, held at $1500^{\circ} \mathrm{C}$ for 20 minutes, and furnace cooled (powered off furnace). The resulting material was subsequently characterized. FY12 work that focused on melt processing in air demonstrated $\mathrm{Cr}$ or a combination of $\mathrm{Cr}$ and $\mathrm{Al}$ in the target hollandite composition, along with $\mathrm{Ti} / \mathrm{TiO}_{2}$ buffers, resulted in single phase hollandite formation with the requisite Cs-incorporation[10]. The current work is focused on evaluating $\mathrm{Cr}-\mathrm{Hol}$ and $\mathrm{Cr} / \mathrm{Al} / \mathrm{Fe}-\mathrm{Hol}$ phase formation in reducing conditions which are anticipated to be utilized in multiphase wasteforms. The following sections show the microstructure and phase identification of three hollandite compositions without $\mathrm{Ti} / \mathrm{TiO}_{2}$ buffer melt processed in $1 \% \mathrm{H}_{2}$ balance Argon reducing gas conditions.

\subsubsection{Fe-Hollandite}

Figure 2-1 displays the microstructure and Table 2-1 summarizes the phase formation of a Fe-Hollandite fabricated by melt and crystallization process in $1 \% \mathrm{H}_{2}$ balance Argon without $\mathrm{Ti} / \mathrm{TiO}_{2}$ buffer. The microstructure was crystalline with some porosity and voids as would be expected from a melt process. The Fe-Hollandite sample showed the presence of several secondary phases including spinels, titanates and aluminates along with the primary hollandite phase. In particular, Cs was found in the $\mathrm{CsAlTiO}_{4}$ phase which is known to be less durable than hollandite which could adversely affect Cs retention during aqueous corrosion. 


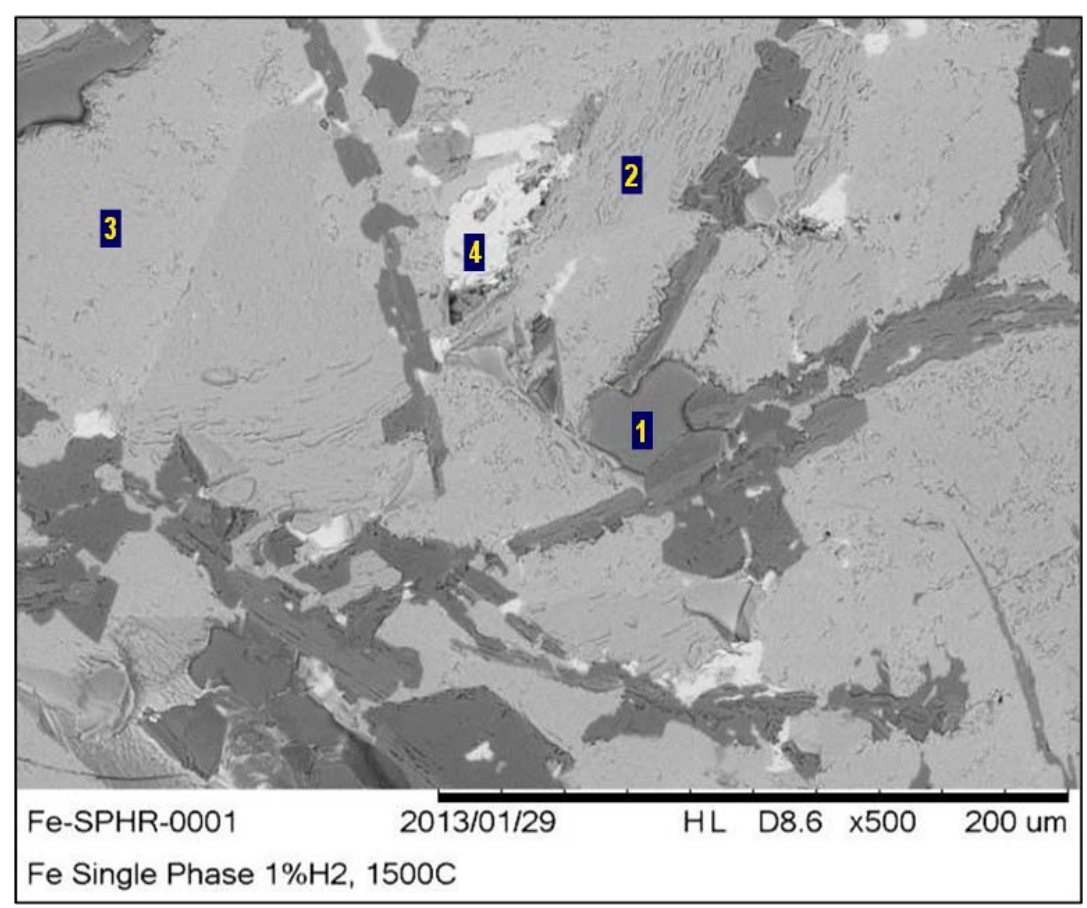

Figure 2-1. Fe-Hollandite Fabricated by Melting and Crystallizing in $1 \% \mathrm{H}_{2}$ balance Argon without $\mathrm{Ti} / \mathrm{TiO}_{2}$ buffer Backscattered Electron Micrograph

Table 2-1. Fe-Hollandite Fabricated by Melting and Crystallizing in $1 \% \mathrm{H}_{2}$ without Ti/TiO $\mathrm{T}_{2}$ buffer Fabricated by Melting and Crystallizing -Summary of Elements and Crystalline Phases (*Crystalline phases determined from $X$-ray Diffraction $X R D$ measurements and Energy Dispersive $X$ ray Spectroscopy EDAX elemental analysis)

\begin{tabular}{|c|l|l||}
\hline Spot & \multicolumn{1}{|c||}{ Elements (Major, Minor) } & \multicolumn{1}{|c|}{ Crystalline Phases* } \\
\hline 1 & $\mathrm{O}, \mathrm{Al}, \mathrm{Fe}, \mathrm{Ti}$ & $\mathrm{FeAl}_{2} \mathrm{O}_{4},\left(\mathrm{~A}^{+3}\right)_{2} \mathrm{TiO}_{5}$ \\
\hline 2,3 & $\mathrm{O}, \mathrm{Ti}, \mathrm{Al}, \mathrm{Fe}, \mathrm{Ba},(\mathrm{Cs})$ & $\mathrm{Hollandite}^{*} \mathrm{Cs}_{2} \mathrm{Cs}_{2} \mathrm{Ti}_{2} \mathrm{O}_{5}, \mathrm{CsAlTiO}_{4}$ \\
\hline 4 & $\mathrm{O}, \mathrm{Ti}, \mathrm{Cs}, \mathrm{Al}$ & $\mathrm{Cl}^{2}$ \\
\hline
\end{tabular}

\subsubsection{Cr Hollandite}

Figure 2-2 displays the phase microstructure and Table 2-2 summarizes the phase formation of CrHollandite fabricated by a melt and crystallization process in $1 \% \mathrm{H}_{2}$ balance Argon without a $\mathrm{Ti} / \mathrm{TiO}_{2}$ buffer. The microstructure is indicative of a solid state reaction mechanism with limited evidence of melting. However, it is suspected that when incorporated into a multiphase waste form, the additional constituents comprising the melt will aid melt processing, even of the high refractory Cr-Hollandite composition. Single phase hollandite with Cs incorporation was primarily observed along with residual $\mathrm{TiO}_{2}$. 


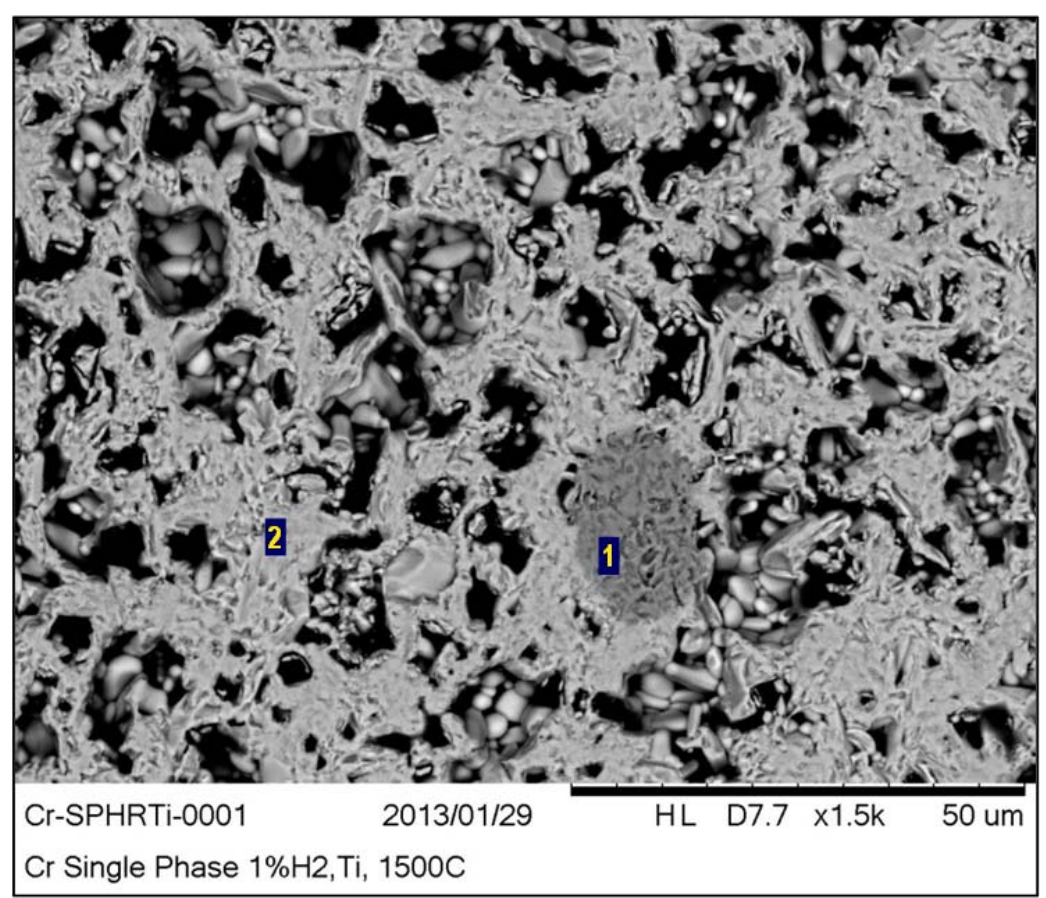

Figure 2-2. Cr-Hollandite Fabricated by Melting and Crystallizing in $1 \% \mathrm{H}_{2}$ balance Argon without $\mathrm{Ti} / \mathrm{TiO}_{2}$ buffer Backscattered Electron Micrograph

Table 2-2. Cr-Hollandite Fabricated by Melting and Crystallizing in $1 \% \mathrm{H}_{2}$ without $\mathrm{Ti} / \mathrm{TiO}_{2}$ buffer Fabricated by Melting and Crystallizing -Summary of Elements and Crystalline Phases (*Crystalline phases determined from XRD measurements and EDAX elemental analysis)

\begin{tabular}{|c|l|l||}
\hline Spot & \multicolumn{1}{|c||}{ Elements (Major, Minor) } & \multicolumn{1}{|c|}{ Crystalline Phases* } \\
\hline 1 & $\mathrm{O}, \mathrm{Ti}$ & $\mathrm{TiO}_{2}$ \\
\hline 2 & $\mathrm{O}, \mathrm{Ti}, \mathrm{Cr}, \mathrm{Cs}, \mathrm{Ba}$ & Hollandite \\
\hline
\end{tabular}

\subsection{3. $\mathrm{Cr} / \mathrm{Al} / \mathrm{Fe}$ Hollandite}

Figure 2-3 displays the microstructure and Table 2-3 tabulates the phase formation of $\mathrm{Cr} / \mathrm{Al} / \mathrm{Fe}-\mathrm{Hollandite}$ melt processed at $1500^{\circ} \mathrm{C}$ without $\mathrm{Ti} / \mathrm{TiO}_{2}$ buffer in $1 \% \mathrm{H}_{2}$ balance Argon reducing atmosphere. The observed microstructure is a combination of the $\mathrm{Fe}$ and $\mathrm{Cr}$ analogues; some areas of the sample appear to have completely melted (Fe) while others exhibit features of solid state sintering ( $\mathrm{Cr}$ ). The primary crystalline phase observed was hollandite along with $\mathrm{Fe}_{2} \mathrm{TiO}_{5}$ spinel secondary phases. 


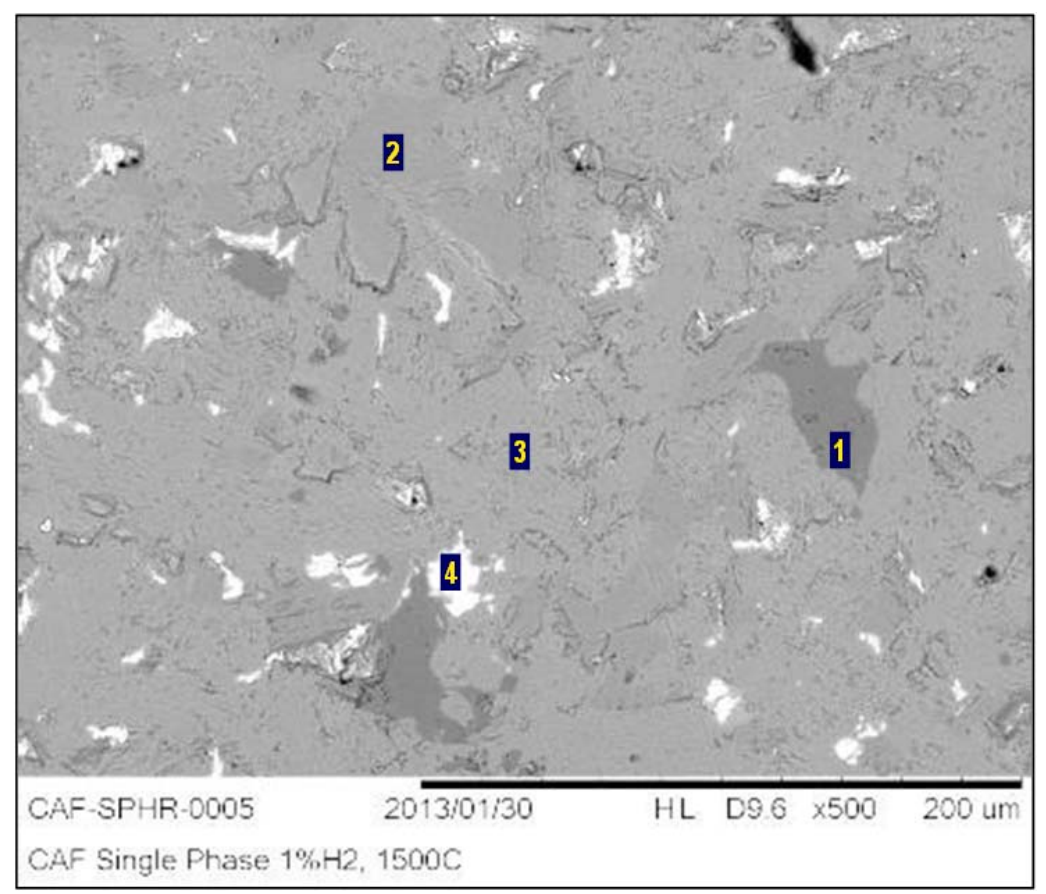

Figure 2-3. Cr/Al/Fe-Hollandite Fabricated by Melting and Crystallizing in $1 \% \mathrm{H}_{2}$ balance Argon without $\mathrm{Ti} / \mathrm{TiO}_{2}$ buffer Backscattered Electron Micrograph

Table 2-3. Cr/Al/Fe-Hollandite Fabricated by Melting and Crystallizing in $1 \% \mathrm{H}_{2}$ without $\mathrm{Ti} / \mathrm{TiO}_{2}$ buffer Fabricated by Melting and Crystallizing -Summary of Elements and Crystalline Phases (*Crystalline phases determined from XRD measurements and EDAX elemental analysis)

\begin{tabular}{|c|l|l|}
\hline Spot & \multicolumn{1}{|c|}{ Elements (Major, Minor) } & \multicolumn{1}{c|}{ Crystalline Phases* } \\
\hline 1 & $\mathrm{O}, \mathrm{Fe}, \mathrm{Al}, \mathrm{Ti}$ & $\mathrm{FeAl}_{2} \mathrm{O}_{4}$ \\
\hline 2,3 & $\mathrm{O}, \mathrm{Ti}, \mathrm{Ba}, \mathrm{Al}, \mathrm{Cr}, \mathrm{Fe}$ & $\mathrm{Hollandite}^{*}$ \\
\hline 4 & $\mathrm{O}, \mathrm{Ti}, \mathrm{Cs}, \mathrm{Al}$ & $\mathrm{Cs}_{2} \mathrm{Ti}_{2} \mathrm{O}_{5}, \mathrm{CsAlTiO}_{4}$ \\
\hline
\end{tabular}

\subsection{Spark Plasma Sintering (SPS)}

Spark Plasma Sintering (SPS) was conducted on a Dr. Sinter Model SPS 515S from Metals Processing Inc. Approximately $1 \mathrm{~g}$ of powder batch was mixed with a $\mathrm{Ti} / \mathrm{TiO}_{2}$ buffer and loaded in a graphite die for SPS processing at temperatures between 1040 and $1240^{\circ} \mathrm{C}$.

\subsubsection{Cr Hollandite}

Figure 2-4 displays the microstructure and Table 2-5 tabulates the phase information for the Cr-Hollandite fabricated by SPS with $\mathrm{Ti} / \mathrm{TiO}_{2}$ buffer at $1240^{\circ} \mathrm{C}$. In general the SPS microstructure was relatively dense without the presence of large voids. Cs was observed in the primary hollandite phase, but was also observed in secondary $\mathrm{Cs}_{2} \mathrm{Ti}_{2} \mathrm{O}_{5}$ phases. 


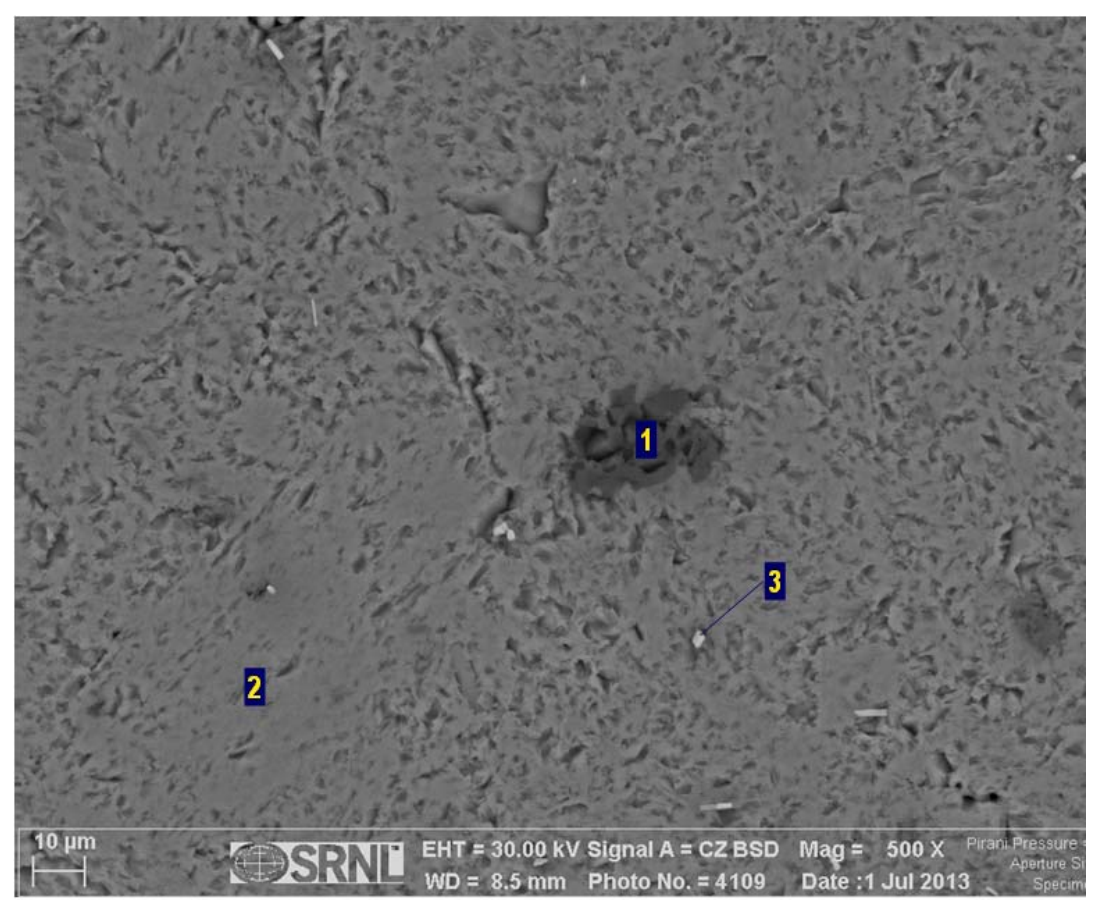

Figure 2-4. Cr-Hollandite Fabricated by SPS with $\mathrm{Ti} / \mathrm{TiO}_{2}$ buffer at $1240^{\circ} \mathrm{C}$ Backscattered Electron Micrograph

Table 2-4. Cr-Hollandite Fabricated by SPS with $\mathrm{Ti} / \mathrm{TiO}_{2}$ at $1240^{\circ} \mathrm{C}$-Summary of Elements and Crystalline Phases (*Crystalline phases determined from XRD measurements and EDAX elemental analysis)

\begin{tabular}{|c|l|l|}
\hline Spot & \multicolumn{1}{|c|}{ Elements (Major, Minor) } & \multicolumn{1}{|c|}{ Crystalline Phases* } \\
\hline 1 & $\mathrm{O}, \mathrm{Ti}$ & $\mathrm{TiO}_{2}$ \\
\hline 2 & $\mathrm{O}, \mathrm{Ti}, \mathrm{Cr}, \mathrm{Ba}, \mathrm{Cs}$ & $\mathrm{Hollandite}^{*} \mathrm{Cl}_{2} \mathrm{O}_{4}$ \\
\hline 3 & $\mathrm{O}, \mathrm{Ti}, \mathrm{Cs}$ & $\mathrm{Cs}_{2} \mathrm{Ti}_{2} \mathrm{O}_{5}, \mathrm{FeAl}_{2}{ }^{2}$ \\
\hline
\end{tabular}

\subsection{2. $\mathrm{Cr} / \mathrm{Al} / \mathrm{Fe}$ Hollandite}

Figure 2-5 displays the microstructure and Table 2-5 tabulates the phases observed in $\mathrm{Cr} / \mathrm{Al} / \mathrm{Fe}-\mathrm{Hollandite}$ with $\mathrm{Ti} / \mathrm{TiO}_{2}$ buffer fabricated by SPS at $1230^{\circ} \mathrm{C}$. Small pores resulting from solid state sintering $(\sim 1$ micron) were observed which were distributed throughout the microstructure. In addition to the primary Cs containing hollandite phase, there were $\mathrm{Cs}_{2} \mathrm{Ti}_{2} \mathrm{O}_{5}$ and $\left(\mathrm{A}^{+3}\right)_{2} \mathrm{TiO}_{5}$ with $\mathrm{A}^{+3=} \mathrm{Fe}, \mathrm{Al}$, Cr secondary phases observed. 


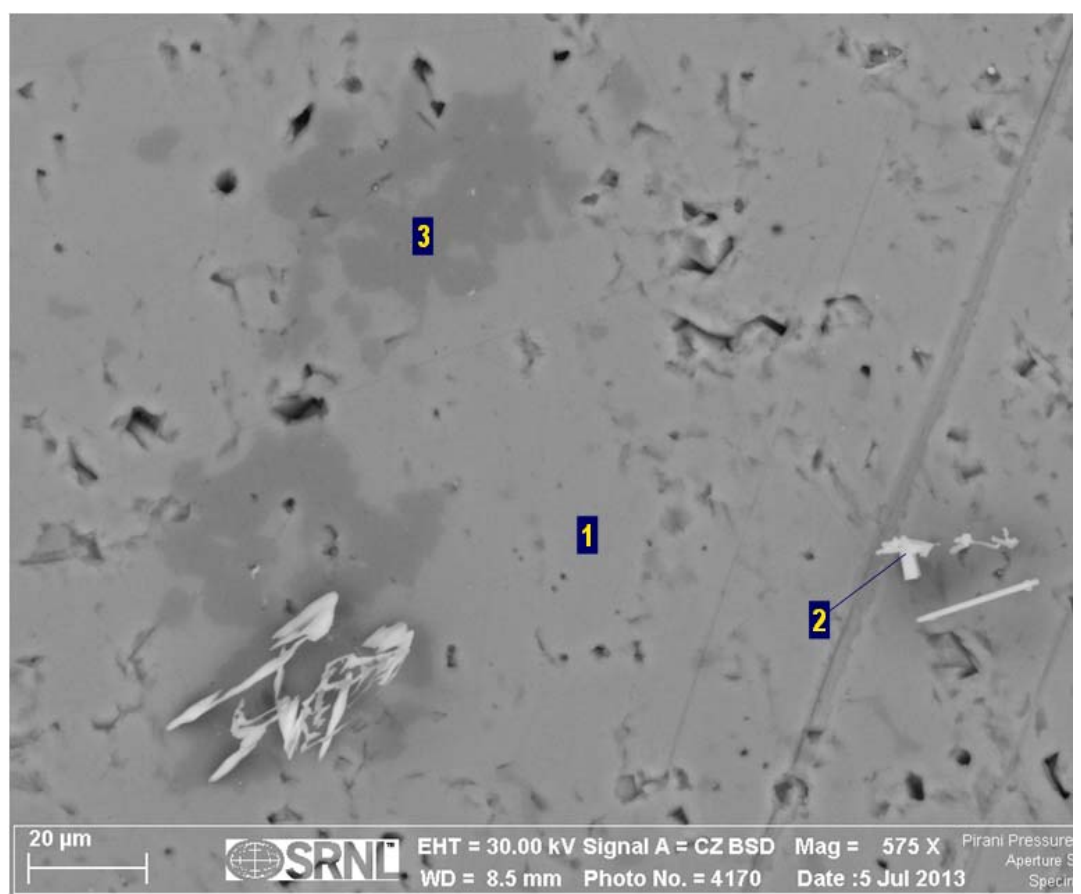

Figure 2-5. $\mathrm{Cr} / \mathrm{Al} / \mathrm{Fe}-\mathrm{Hollandite} \mathrm{Fabricated} \mathrm{by} \mathrm{SPS} \mathrm{with} \mathrm{Ti} / \mathrm{TiO}_{2}$ buffer at $1230^{\circ} \mathrm{C} \mathrm{Backscattered}$ Electron Micrograph

Table 2-5. Cr/Al/Fe-Hollandite Fabricated by SPS with $\mathrm{Ti} / \mathrm{TiO}_{2}$ buffer at $1230^{\circ} \mathrm{C}$-Summary of Elements and Crystalline Phases (*Crystalline phases determined from XRD measurements and EDAX elemental analysis)

\begin{tabular}{|c|l|l|}
\hline Spot & \multicolumn{1}{|c|}{ Elements (Major, Minor) } & \multicolumn{1}{|c|}{ Crystalline Phases* } \\
\hline 1 & $\mathrm{O}, \mathrm{Ti}, \mathrm{Cr}, \mathrm{Al}, \mathrm{Fe}, \mathrm{Ba}, \mathrm{Cs}$ & $\mathrm{Hollandite}^{*}$ \\
\hline 2 & $\mathrm{O}, \mathrm{Ti}, \mathrm{Cs}$ & $\mathrm{Cs}_{2} \mathrm{Ti}_{2} \mathrm{O}_{5}$ \\
\hline 3 & $\mathrm{O}, \mathrm{Ti}, \mathrm{Cr}, \mathrm{Al}, \mathrm{Fe}$ & $\left(\mathrm{A}^{+3}\right)_{2} \mathrm{TiO}_{5}$ \\
\hline
\end{tabular}

\subsection{Hot Pressing (HP)}

The hot pressing procedure consisted of an initial $10^{\circ} \mathrm{C} / \mathrm{min}$ ramp to a temperature of $1200^{\circ} \mathrm{C}$ where the sample was held for 2 hours followed by a decrease of the temperature to $1000^{\circ} \mathrm{C}$ in 15 minutes and finally shutting off the furnace and allowing the sample to cool to room temperature in approximately 2.5 hours. The pressure was maintained at 40+/-1 MPa with nitrogen gas supplied at a flow rate of $40 \mathrm{ml} / \mathrm{min}$ during the hot press procedure.

\subsubsection{Cr Hollandite}

Figure 2-6 displays the microstructure and Table 2-6 tabulates the phases observed in Cr-Hollandite with $\mathrm{Ti} / \mathrm{TiO}_{2}$ buffer fabricated by $\mathrm{HP}$ at $1200^{\circ} \mathrm{C}$ for 2 hours (40MPA, $\mathrm{N}_{2}$ gas). The sample appears relatively dense with small pores ( 1-5 micron) which were distributed throughout the microstructure. In addition to the primary Cs containing hollandite phase, there was residual $\mathrm{Cr}_{2} \mathrm{O}_{3}$ and $\mathrm{TiO}_{2}$ detected. 


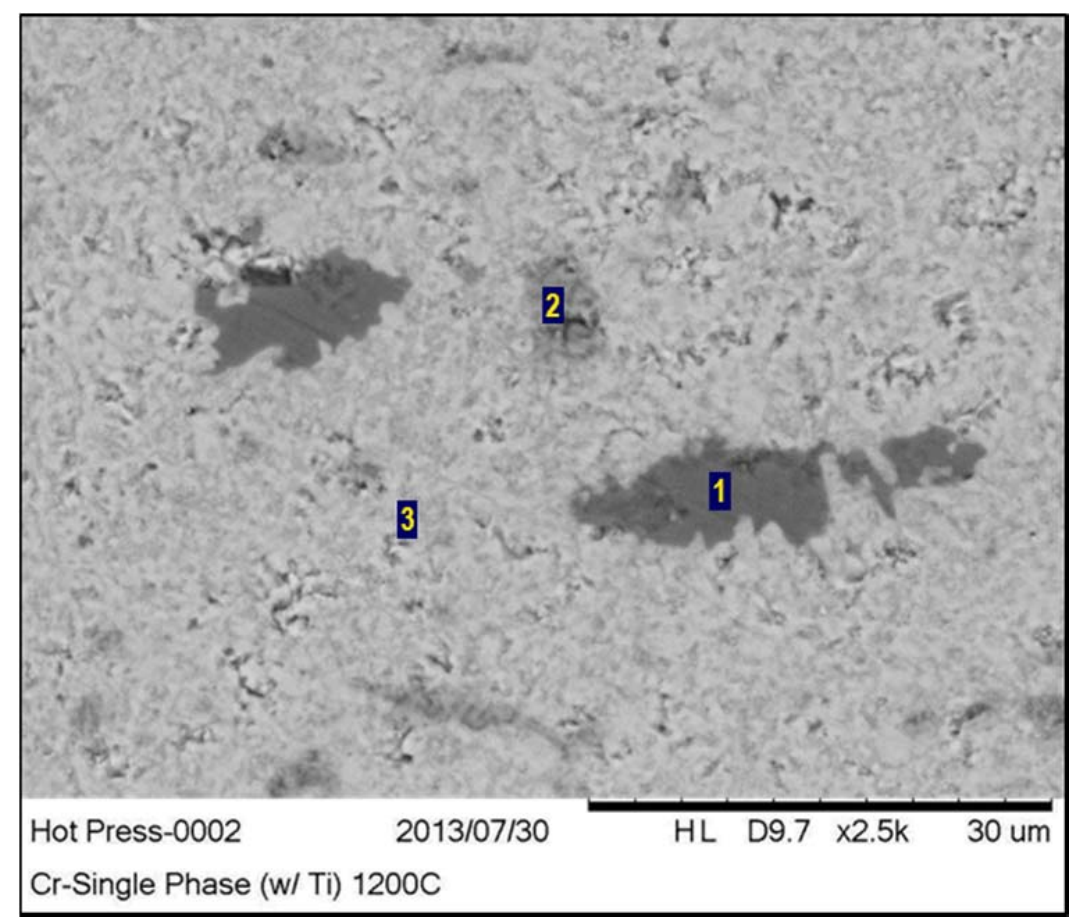

Figure 2-6. Cr-Hollandite with $\mathrm{Ti} / \mathrm{TiO}_{2}$ buffer Fabricated by $\mathrm{HP}$ at $40 \mathrm{MPa}$ under $\mathrm{N}_{2}$ gas at $1200^{\circ} \mathrm{C}$ for 2 hours- Backscattered Electron Micrograph

Table 2-6. $\mathrm{Cr}$-Hollandite with $\mathrm{Ti} / \mathrm{TiO}_{2}$ buffer Fabricated by $\mathrm{HP}$ at $40 \mathrm{MPa}$ under $\mathrm{N}_{2}$ gas at $1200^{\circ} \mathrm{C}$ for 2 hours -Summary of Elements and Crystalline Phases (*Crystalline phases determined from XRD measurements and EDAX elemental analysis)

\begin{tabular}{|c|l|l|}
\hline Spot & Elements (Major, Minor) & \multicolumn{1}{|c|}{ Crystalline Phases* } \\
\hline 1 & $\mathrm{O}, \mathrm{Ti}$ & $\mathrm{TiO}_{2}$ \\
\hline 2 & $\mathrm{O}, \mathrm{Cr}$ & $\mathrm{Cr}_{2} \mathrm{O}_{3}$ \\
\hline 3 & $\mathrm{O}, \mathrm{Ti}, \mathrm{Cr}, \mathrm{Ba}, \mathrm{Cs}$ & $\mathrm{Hollandite}$ \\
\hline
\end{tabular}

\subsection{2. $\mathrm{Cr} / \mathrm{Al} / \mathrm{Fe}$ Hollandite}

Figure 2-7 displays the microstructure and Table 2-7 tabulates the phases observed in $\mathrm{Cr} / \mathrm{Al} / \mathrm{Fe}-\mathrm{Hollandite}$ with $\mathrm{Ti} / \mathrm{TiO}_{2}$ buffer fabricated by $\mathrm{HP}$ at $1200^{\circ} \mathrm{C}$ for 2 hours (40MPA, $\mathrm{N}_{2}$ gas). The sample appears is similar to the pure $\mathrm{Cr}$ analogue and is relatively dense with small pores ( 1-5 micron) which were distributed throughout the microstructure. In addition to the primary Cs containing hollandite phase, there was residual $\mathrm{Cr}_{2} \mathrm{O}_{3}$ and $\mathrm{Fe}$ oxide and $\mathrm{Al}_{2} \mathrm{O}_{3}$ detected. 


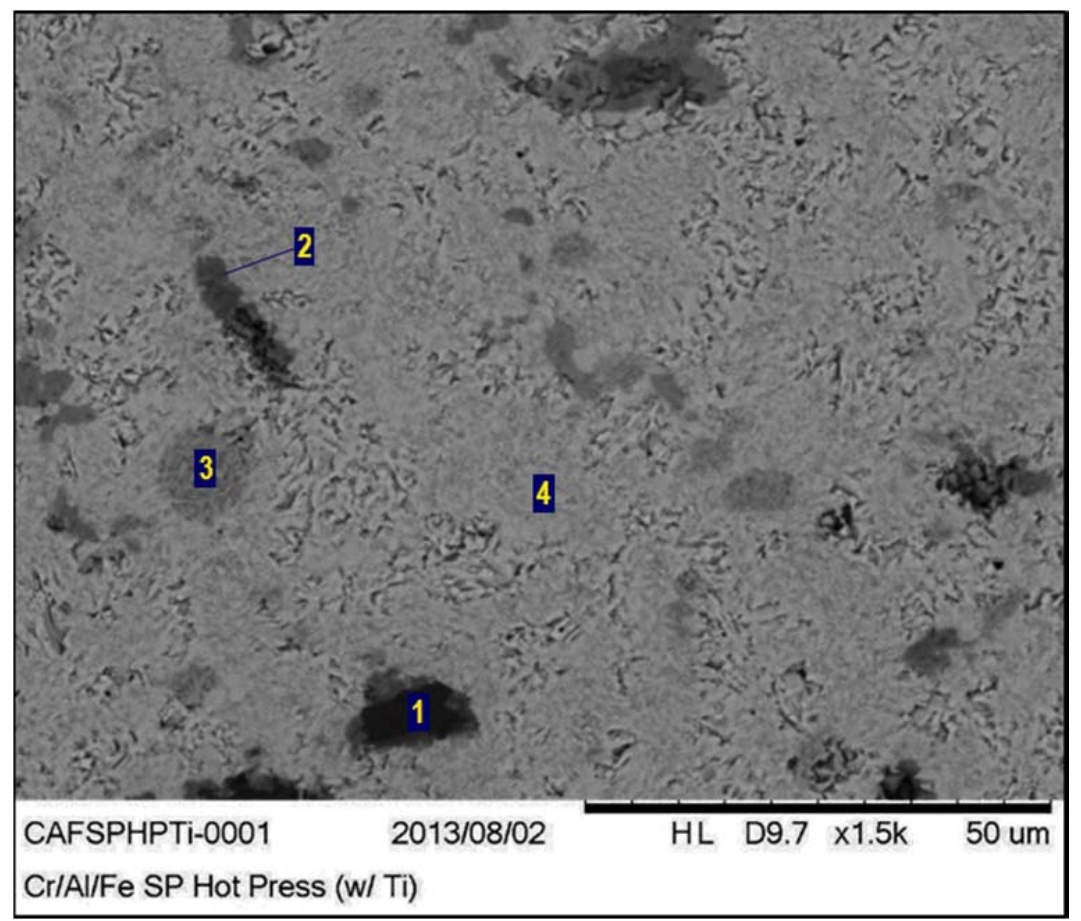

Figure 2-7. $\mathrm{Cr} / \mathrm{Al} / \mathrm{Fe}-\mathrm{Hollandite}$ with $\mathrm{Ti} / \mathrm{TiO}_{2}$ buffer Fabricated by $\mathrm{HP}$ at $40 \mathrm{MPa}$ under $\mathrm{N}_{2}$ gas at $1200^{\circ} \mathrm{C}$ for 2 hours- Backscattered Electron Micrograph

Table 2-7. $\mathrm{Cr} / \mathrm{Al} / \mathrm{Fe}-\mathrm{Hollandite}$ with $\mathrm{Ti} / \mathrm{TiO}_{2}$ buffer Fabricated $\mathrm{HP}$ at $40 \mathrm{MPa}$ under $\mathrm{N}_{2}$ gas at $1200^{\circ} \mathrm{C}$ for 2 hours -Summary of Elements and Crystalline Phases $\left({ }^{*}\right.$ Crystalline phases determined from XRD measurements and EDAX elemental analysis)

\begin{tabular}{|c|l|l||}
\hline Spot & Elements (Major, Minor) & \multicolumn{1}{c|}{ Crystalline Phases* } \\
\hline 1 & $\mathrm{O}, \mathrm{Al}$ & $\mathrm{Al}_{2} \mathrm{O}_{3}$ \\
\hline 2 & $\mathrm{O}, \mathrm{Fe},(\mathrm{Al})$ & $\mathrm{Iron}$ Oxide \\
\hline 3 & $\mathrm{O}, \mathrm{Cr},(\mathrm{Fe})$ & $\mathrm{Cr}_{2} \mathrm{O}_{3}$ \\
\hline 4 & $\mathrm{O}, \mathrm{Ti}, \mathrm{Cr}, \mathrm{Ba}, \mathrm{Cs}$ & Hollandite \\
\hline
\end{tabular}


Table 2-8. Single Phase Hollandite Characterization Summary ${ }^{\mathrm{a}}$

\begin{tabular}{|c|c|c|c|}
\hline Short Identifier ${ }^{a}$ & $\begin{array}{l}\text { Major } \\
\text { Phase }\end{array}$ & Minor Phase(s) ${ }^{\mathbf{b}}$ & $\begin{array}{l}\text { Processing } \\
\text { Conditions }\end{array}$ \\
\hline \multicolumn{4}{|l|}{ Melt Processing } \\
\hline Fe-SPH & Hollandite & $\mathrm{Fe}_{2} \mathrm{TiO}_{5} ; \mathrm{Fe}_{2} \mathrm{Ti}_{3} \mathrm{O}_{9}$ & Air \\
\hline Fe-SPH-Ti & Hollandite & $\mathrm{Fe}_{3} \mathrm{Ti}_{3} \mathrm{O}_{10} ; \mathrm{CsTiAlO} ; \mathrm{Fe}_{2} \mathrm{O}_{3}$ & Air w/Ti-TiO 2 \\
\hline Fe-SPHR & Hollandite & $\begin{array}{ll}\mathrm{Al}_{2} \mathrm{TiO}_{5} ; & \mathrm{BaFe}_{12} \mathrm{O}_{19} ; \\
\mathrm{FeAl}_{2} \mathrm{O}_{4} & \end{array}$ & $1 \% \mathrm{H}_{2}$ \\
\hline Fe-SPHR-Ti & Hollandite & $\mathrm{Al}_{2} \mathrm{O}_{3} ; \mathrm{FeAl}_{2} \mathrm{O}_{4}$ & $1 \% \mathrm{H}_{2} \mathrm{w} / \mathrm{Ti}-\mathrm{TiO}_{2}$ \\
\hline Cr-SPH & Hollandite & & Air \\
\hline Cr-SPH-Ti & Hollandite & $\mathrm{TiO}_{2}$ & Air w/Ti-TiO ${ }_{2}$ \\
\hline Cr-SPHR & Hollandite & & $1 \% \mathrm{H}_{2}$ \\
\hline Cr-SPHR-Ti & Hollandite & $\mathrm{TiO}_{2}$ & $1 \% \mathrm{H}_{2} \mathrm{w} / \mathrm{Ti}-\mathrm{TiO}_{2}$ \\
\hline CAF-SPH & Hollandite & & Air \\
\hline CAF-SPH-Ti & Hollandite & $\mathrm{Fe}_{2} \mathrm{TiO}_{4}$ & Air w/Ti-TiO ${ }_{2}$ \\
\hline CAF-SPHR & Hollandite & $\mathrm{FeAl}_{2} \mathrm{O}_{4}$ & $1 \% \mathrm{H}_{2}$ \\
\hline CAF-SPHR-Ti & Hollandite & $\mathrm{FeAl}_{2} \mathrm{O}_{4}$ & $1 \% \mathrm{H}_{2} \mathrm{w} / \mathrm{Ti}-\mathrm{TiO}_{2}$ \\
\hline \multicolumn{4}{|c|}{ Spark Plasma Sintering (SPS) } \\
\hline Cr-SPH-SPS-1040 & Hollandite & $\mathrm{Cr}_{2} \mathrm{O}_{3}, \mathrm{Cs}_{2} \mathrm{Ti}_{2} \mathrm{O}_{5}$ & $1040^{\circ} \mathrm{C}$ w $/ \mathrm{Ti}-\mathrm{TiO}_{2}$ \\
\hline Cr-SPH-SPS-1240 & Hollandite & $\mathrm{Cr}_{2} \mathrm{O}_{3}, \mathrm{Cs}_{2} \mathrm{Ti}_{2} \mathrm{O}_{5}$ & $1240^{\circ} \mathrm{C} \mathrm{w} / \mathrm{Ti}-\mathrm{TiO}_{2}$ \\
\hline CAF-SPH-SPS-1040 & Hollandite & & $1040^{\circ} \mathrm{C}$ w $/ \mathrm{Ti}-\mathrm{TiO}_{2}$ \\
\hline CAF-SPH-SPS-1230 & Hollandite & $\mathrm{Fe}_{2} \mathrm{TiO}_{5}$ & $1230^{\circ} \mathrm{C} \mathrm{w} / \mathrm{Ti}-\mathrm{TiO}_{2}$ \\
\hline \multicolumn{4}{|l|}{ Hot Pressing } \\
\hline Cr-SPH-HP & Hollandite & $\mathrm{Cr}_{2} \mathrm{O}_{3}$ & $\mathrm{~N}_{2}, 1200^{\circ} \mathrm{C}$ \\
\hline Cr-SPH-HP-Ti & Hollandite & $\mathrm{Cr}_{2} \mathrm{O}_{3}$ & $\mathrm{~N}_{2}, 1200^{\circ} \mathrm{C}, \mathrm{w} / \mathrm{Ti}-\mathrm{TiO}_{2}$ \\
\hline CAF-SPH-HP & Hollandite & $\mathrm{BaFe}_{12} \mathrm{O}_{19}$ & $\mathrm{~N}_{2}, 1200^{\circ} \mathrm{C}$ \\
\hline CAF-SPH-HP-Ti & Hollandite & & $\mathrm{N}_{2}, 1200^{\circ} \mathrm{C}, \mathrm{w} / \mathrm{Ti}-\mathrm{TiO}_{2}$ \\
\hline
\end{tabular}

Table 2-8 summarizes the phase formation versus composition and processing conditions for single phase hollandite samples fabricated in this study. Experiments have shown that reducing agents and atmospheres affect hollandite formation and Cs incorporation. Under reducing conditions, samples batched with $\mathrm{Fe}_{2} \mathrm{O}_{3}$ are expected to be rich in $\mathrm{FeO}$ and $\mathrm{Al}_{2} \mathrm{O}_{3}$ leading to $\mathrm{FeAl}_{2} \mathrm{O}_{4}$ spinel formation. Thus, the hollandite composition (relative to targeted hollandite) was deficient in Fe and $\mathrm{Al}$. The Fe-Al compounds were observed in all Fe containing samples irrespective of processing method, whereas the Cr-hollandite samples exhibited single phase hollandite formation under both reducing and oxidizing environments. X-ray PhotoElectron Spectroscopy (XPS) and X-ray Absorption spectroscopy (XANES) were used to probe the $\mathrm{Cr}$ and $\mathrm{Fe}$ oxidization states in melt processed samples. The results indicated that the $\mathrm{Cr}$ valence was unchanged across the reducing spectrum from air to $1 \% \mathrm{H}_{2}$ gas with $\mathrm{Ti} / \mathrm{TiO}_{2}$ buffer additions, while the Fe was reduced under reducing conditions.[20] The use of $\mathrm{Cr}$ and $\mathrm{Ti} / \mathrm{TiO}_{2}$ buffer appears to stabilize the hollandite structure and promote Cs incorporation. This work suggests that $\mathrm{Cr}$ preferentially enters the hollandite phase (even in the presence of competing phases) because it does not

\footnotetext{
a “Fe-..." targeted $\mathrm{Ba}_{1.0} \mathrm{Cs}_{0.3} \mathbf{F e}_{2.3} \mathrm{Ti}_{5.7} \mathrm{O}_{16}$ Hollandite; “Cr-..." targeted $\mathrm{Ba}_{1.0} \mathrm{Cs}_{0.3} \mathbf{C r}_{2.3} \mathrm{Ti}_{5.7} \mathrm{O}_{16}$ Hollandite; “CAF-..." targeted $\mathrm{Ba}_{1.0} \mathrm{Cs}_{0.3} \mathbf{C r}_{1.0} \mathbf{A l}_{0.3} \mathbf{F e}_{1.0} \mathrm{Ti}_{5.7} \mathrm{O}_{16}$ Hollandite.

b The phases listed in this column have a known amount of ambiguity as they are based on semi-quantitative analysis and previous conclusions; they should be taken to represent the general types of compounds forming and species in those compounds.
} 
readily form compounds with Cs and it is not easily susceptible to reduction. The potential drawback to $\mathrm{Cr}$ additions includes the elevated temperatures required for melting as compared to $\mathrm{Fe} / \mathrm{Al}$ analogues.

This work demonstrated the melt processing of single phase hollandite in air and reducing environments by tailoring the composition and using solid state $\mathrm{Ti} / \mathrm{TiO}_{2}$ buffer. The hollandite phase formation incorporating Cs is comparable with the HP and SPS methods investigated. Major differences between the melt processed and alternative sintering routes include an increase in grain size in melt processed samples accompanied by few, but large voids (> 10 micron size) due to the melt process. In contrast, the SPS and HP process have many, but small voids ( 1-5 micron in size) well distributed throughout the materials. With the observed differences in microstructure with varying process conditions, the impact of microstructure on materials durability should be the focus of future studies. These results indicate that Csincorporation into a stable hollandite phase is possible under the reducing conditions anticipated in multiphase systems. However, while reducing conditions may eliminate the formation of non-durable molybdate phases, these same reducing conditions increase the tendency for variable valance species such as Fe to form secondary phases along with the targeted hollandite. The ability to tailor hollandite stoichiometry in complex multiphase systems may be a key factor in choice of processing routes and ultimately material performance.

\section{MULTIPHASE SYTEMS}

The single phase hollandite compositions $\mathrm{Cr}-\mathrm{Hol}$, and $\mathrm{Cr} / \mathrm{Al} / \mathrm{F}-\mathrm{Hol}$ which demonstrated the best phase formation under reducing conditions were incorporated into multiphase ceramics targeting hollandite, perovskite/pyrochlore and zirconolite phase assemblages from combined Cs/Sr, lanthanide, and transition metal (including Mo) waste streams.

\subsection{Composition Development and Processing Conditions}

The design and calculation of reference ceramic host systems for FCR\&D waste streams was presented in the FY12 report "Crystalline Ceramic Waste Forms: Reference Formulation Report”.[9] In this work, optimized single phase hollandite compositions based on $\mathrm{Cr}$ and $\mathrm{Cr} / \mathrm{Al} / \mathrm{Fe}$ additions were incorporated into multiphase ceramics targeting hollandite, perovskite/pyrochlore and zirconolite phase assemblages from combined Cs/Sr, lanthanide, and transition metal (including Mo) waste streams. Two different multiphase compositions were prepared as described in Table 3-1 with $\sim 25$ weight \% waste loading and varying concentrations of $\mathrm{CaO}, \mathrm{Al}_{2} \mathrm{O}_{3}, \mathrm{BaO}, \mathrm{Cr}_{2} \mathrm{O}_{3}, \mathrm{Fe}_{2} \mathrm{O}_{3}$ and $\mathrm{TiO}_{2}$ additives. The chemical composition (batch sheets) of these two samples compared to literature SYNROC-C formulations is given in Table 3-2. Details of the simulated waste, additives, and melting and crystalizing processes, and characterization are described in the FY10 and FY11 and FY12 reports.[9, 21, 22]

Similar to the single phase hollandite work presented in Section 2, a combination of gas phase environment and solid state reducing agents were used to vary the redox conditions using different processing techniques: i) melt processing of compositions with and without $\mathrm{Ti} / \mathrm{TiO}_{2}$ buffer in air and $1 \% \mathrm{H}_{2}$ /balance Argon gas environments, ii) vacuum induction melting at $10^{-6}$ atm and $1500^{\circ} \mathrm{C}$ with and without $\mathrm{Ti} / \mathrm{TiO}_{2}$ buffer iii) spark plasma sintering with a $\mathrm{Ti} / \mathrm{TiO}_{2}$ buffer in $\mathrm{N}_{2}$ gas at varying temperatures and iv) hot press with and without $\mathrm{Ti} / \mathrm{TiO}_{2}$ buffer in $\mathrm{N}_{2}$ gas at varying temperatures.

The microstructures of select samples are presented along with a table indicating the elemental composition and crystalline phases observed in each section. A summary of the entirety of results on multiphase waste forms across composition and processing method and reducing conditions is summarized in a table at the end of Section 3.5. 
Table 3-1. Ceramic Waste Form Compositions for SRNL Multiphase Melt Samples compared to SYNROC-C[11]; weight percent of oxide component

\begin{tabular}{|c|c|c|c||}
\hline \hline Composition & Cr-MP & CAF-MP & SYNROC-C $^{\mathbf{a}}$ \\
\hline Waste & 24.58 & 24.66 & 19.81 \\
\hline $\mathrm{Al}_{2} \mathrm{O}_{3}$ & 0 & 1.27 & 4.63 \\
\hline $\mathrm{TiO}_{2}$ & 49.01 & 49.16 & 61.4 \\
\hline $\mathrm{CaO}$ & 1.38 & 1.39 & 9.59 \\
\hline $\mathrm{BaO}$ & 10.52 & 10.56 & 4.57 \\
\hline $\mathrm{Fe}_{2} \mathrm{O}_{3}$ & 0 & 6.65 & 0.894 \\
\hline $\mathrm{Cr}_{2} \mathrm{O}_{3}$ & 14.50 & 6.33 & - \\
\hline
\end{tabular}

Table 3-2. Chemical Composition (Batch Sheets) of SRNL Multiphase Melt Samples compared to SYNROC-C[11]; weight percent of oxide component

\begin{tabular}{|l|c|c|c||}
\hline \multicolumn{1}{|c|}{ Oxides } & Cr-MP & CAF-MP & SYNROC-C \\
\hline $\mathrm{Al}_{2} \mathrm{O}_{3}$ & 0.00 & 1.27 & 6.77 \\
\hline $\mathrm{CaO}$ & 1.38 & 1.39 & 10.42 \\
\hline $\mathrm{CdO}$ & 0.11 & 0.11 & - \\
\hline $\mathrm{Cr}_{2} \mathrm{O}_{3}$ & 14.50 & 6.33 & - \\
\hline $\mathrm{Eu}_{2} \mathrm{O}_{3}$ & 0.17 & 0.17 & 0.894 \\
\hline $\mathrm{Fe}_{2} \mathrm{O}_{3}$ & 0.00 & 6.65 & 1.15 \\
\hline $\mathrm{Gd}_{2} \mathrm{O}_{3}$ & 0.16 & 0.16 & $x$ \\
\hline $\mathrm{SrO}$ & 0.98 & 0.98 & 1.17 \\
\hline $\mathrm{TiO}_{2}$ & 49.01 & 49.16 & 58.3 \\
\hline $\mathrm{ZrO}_{2}$ & 2.98 & 2.99 & 8.4 \\
\hline $\mathrm{BaO}_{\mathrm{Ce}}$ & 12.72 & 12.76 & 4.73 \\
\hline $\mathrm{Ce}_{2} \mathrm{O}_{3}$ & 3.09 & 3.10 & $x$ \\
\hline $\mathrm{Cs}_{2} \mathrm{O}$ & 2.87 & 2.88 & 0.53 \\
\hline $\mathrm{La}_{2} \mathrm{O}_{3}$ & 1.58 & 1.58 & $x$ \\
\hline $\mathrm{MoO}_{3}$ & 0.84 & 0.85 & 2.36 \\
\hline $\mathrm{Nd}_{2} \mathrm{O}_{3}$ & 5.22 & 5.23 & $x$ \\
\hline $\mathrm{Pr}_{2} \mathrm{O}_{3}$ & 1.44 & 1.45 & $x$ \\
\hline $\mathrm{SeO}_{2}$ & 0.08 & 0.08 & - \\
\hline $\mathrm{SnO}_{2}$ & 0.07 & 0.07 & - \\
\hline $\mathrm{Sm}_{2} \mathrm{O}_{3}$ & 1.07 & 1.08 & $x$ \\
\hline $\mathrm{TeO}_{2}$ & 0.65 & 0.66 & - \\
\hline $\mathrm{Y}_{2} \mathrm{O}_{3}$ & 0.63 & 0.63 & $x$ \\
\hline $\mathrm{Rb}_{2} \mathrm{O}$ & 0.42 & 0.42 & - \\
\hline $\mathrm{Total}_{\mathrm{REE}_{2} \mathrm{O}_{3}}$ & 13.19 & 13.23 & $6.10^{\mathrm{b}}$ \\
\hline & & & \\
\hline
\end{tabular}

\footnotetext{
${ }^{a}$ SYNCROC-C cited was material prepared by melting of an oxide-nitrate mixture. Crystalline oxides of $\mathrm{Ca}, \mathrm{Ba}, \mathrm{Fe}, \mathrm{Ni}, \mathrm{Al}, \mathrm{Mo}, \mathrm{Ti}$ and $\mathrm{Zr}$ and nitrates of $\mathrm{Cs}, \mathrm{Sr}, \mathrm{Nd}, \mathrm{Gd}$ and Ce were mixed and melt processed. SYNROC-C samples also contained oxide additions of Si, Mg, Co, Ni, Na, and K.[11] 11. Sobolev, I.A., et al., Comparative Study of Synroc-C Ceramics Produced by HotPressing and Inductive Melting. Mater. Res. Soc. Symp. Proc., 1997. 465: p. 371.

${ }^{\mathrm{b}}$ The $6.19 \mathrm{wt} \%$ for total Rare Earth (REE2O3) oxides in SYNROC-C was the sum of the " $\mathrm{x}$ " wt.\% of individual oxides which were not specified.
} 


\subsection{Melt Processing}

Approximately 20g samples of feed stock were loosely placed into a covered alumina crucible. The samples were heated in air and in $1 \% \mathrm{H}_{2}$ (balance Argon) reducing atmosphere. Samples were heated at approximately $15^{\circ} \mathrm{C} / \mathrm{min}$, held at $1500^{\circ} \mathrm{C}$ for 20 minutes, and furnace cooled (powered off furnace). The resulting material was subsequently characterized.

\subsubsection{Cr- Hollandite Multiphase Waste form}

Figure 3-1 displays the microstructure and Table 3-3 tabulates the phases observed in Cr-Hollandite with $\mathrm{Ti} / \mathrm{TiO}_{2}$ buffer fabricated by Melt Processing $1500^{\circ} \mathrm{C}$ in $1 \% \mathrm{H}_{2} /$ balance Argon atmosphere. It should be noted that this conditions comprising solid state reducing agents ( $\mathrm{Ti}$ metal) as well as $1 \% \mathrm{H}_{2}$ gas environments represent the most extreme reducing studied in this work. In contrast to the single phase Cr-Hollandite which exhibited solid state sintering, the multiphase waste showed a microstructure indicative of melting. The targeted crystalline phases were formed including hollandite, zirconolite, perovskite/pyrochlore along with residual $\mathrm{TiO}_{2}$.

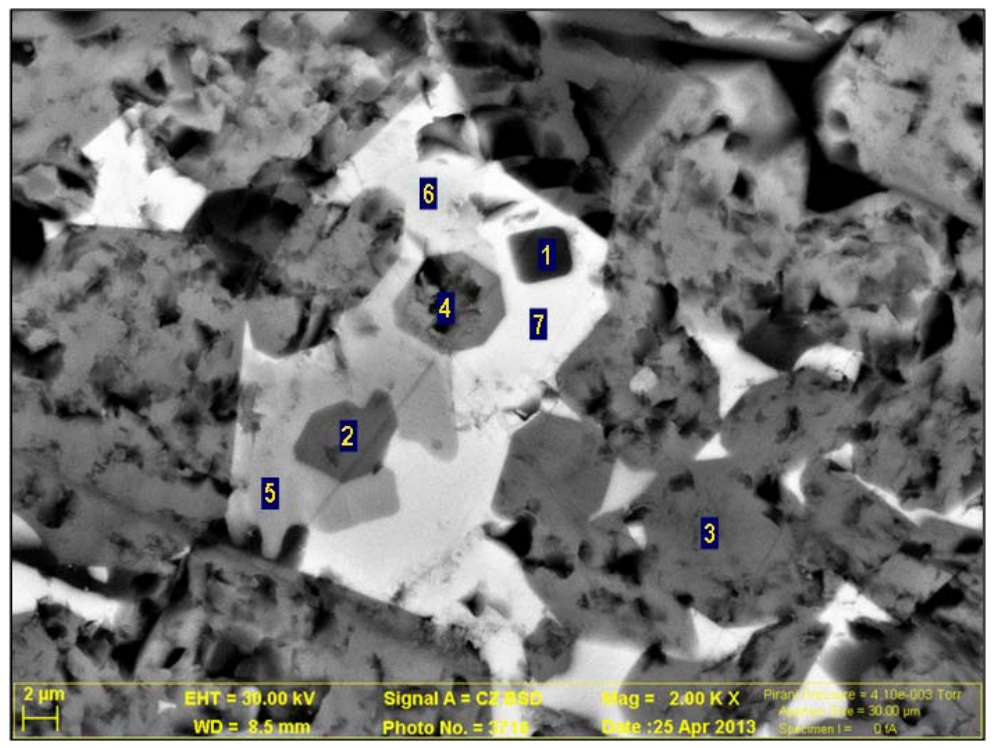

Figure 3-1. Cr-Hollandite Multiphase Waste Form (Cr-MPB1R-Ti) Fabricated Melt Processing $1500^{\circ} \mathrm{C}$ with $\mathrm{Ti} / \mathrm{TiO}_{2}$ buffer additions in $1 \% \mathrm{H}_{2} /$ balance Argon atmosphere- Backscattered Electron Micrograph

Table 3-3. Cr-Hollandite Multiphase Waste Form (Cr-MPB1R-Ti) Fabricated Melt Processing $1500^{\circ} \mathrm{C}$ with $\mathrm{Ti} / \mathrm{TiO}_{2}$ buffer additions in $1 \% \mathrm{H}_{2} /$ balance Argon atmosphere- Summary of Elements and Crystalline Phases ( ${ }^{*}$ Crystalline phases determined from XRD measurements and EDAX elemental analysis)

\begin{tabular}{|c|l|l||}
\hline Spot & \multicolumn{1}{|c|}{ Elements (Major, Minor) } & \multicolumn{1}{|c|}{ Crystalline Phases* } \\
\hline 1 & $\mathrm{O}, \mathrm{Ti},(\mathrm{Cr}, \mathrm{Zr})$ & $\mathrm{TiO}_{2}$ \\
\hline $2,3,4$ & $\mathrm{O}, \mathrm{Ti}, \mathrm{Cr}, \mathrm{Ba},(\mathrm{Al}, \mathrm{Ca}, \mathrm{Zr}, \mathrm{Cs}, \mathrm{La}, \mathrm{Nd})$ & $\mathrm{Hollandite}$ \\
\hline 5 & $\mathrm{O}, \mathrm{Ti}, \mathrm{Ca}, \mathrm{Zr},(\mathrm{Y}, \mathrm{Cr}, \mathrm{Nd})$ & $\mathrm{CaZrTi} \mathrm{O}_{7}$ \\
\hline 6 & $\mathrm{O}, \mathrm{Ti},(\mathrm{Ca}, \mathrm{Y}, \mathrm{Zr}, \mathrm{Ce}, \mathrm{Nd})$ & $\left(\mathrm{A}^{3+}\right)_{2} \mathrm{TiO}_{5}$ \\
\hline 7 & $\mathrm{O}, \mathrm{Ti},(\mathrm{Ca}, \mathrm{Cr}, \mathrm{La}, \mathrm{Ce}, \mathrm{Pr}, \mathrm{Nd})$ & $\left(\mathrm{A}^{3+}\right)_{2} \mathrm{TiO}_{5},\left(\mathrm{La}_{0.4} \mathrm{Ca}_{0.4} \mathrm{TiO}_{3}\right)$ \\
\hline
\end{tabular}




\subsubsection{Cr/Al/Fe Hollandite Multiphase Waste form}

Figure 3-2 displays the microstructure and Table 3-4 tabulates the phases observed in $\mathrm{Cr} / \mathrm{Al} / \mathrm{Fe}-\mathrm{Hollandite}$ with $\mathrm{Ti} / \mathrm{TiO}_{2}$ buffer fabricated by Melt Processing at $1500^{\circ} \mathrm{C}$ in $1 \% \mathrm{H}_{2} /$ balance Argon atmosphere. The multiphase waste form showed grain structure indicative of melting. The targeted crystalline phases were formed including hollandite, zirconolite, perovskite/pyrochlore along with residual $\mathrm{Al}_{2} \mathrm{O}_{3}, \mathrm{Fe}_{2} \mathrm{O}_{3}$ and $\mathrm{TiO}_{2}$.

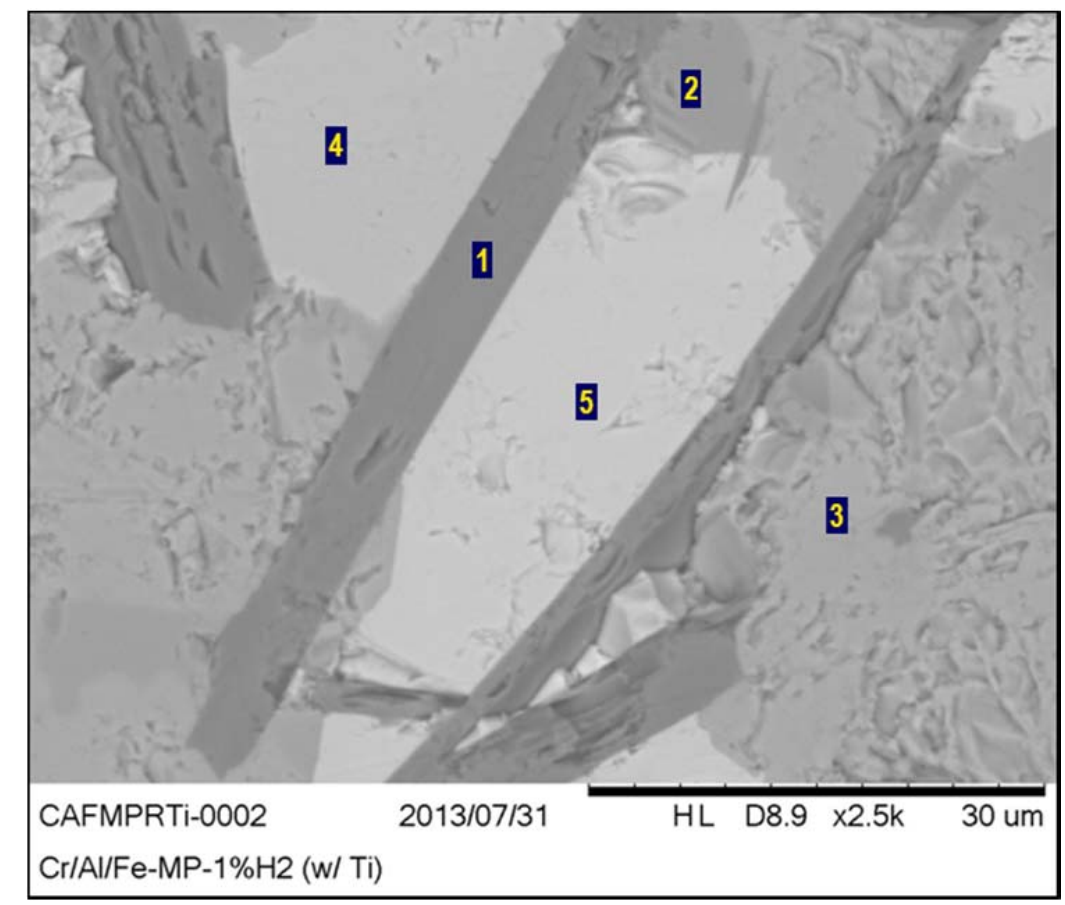

Figure 3-2. Cr/Al/Fe-Hollandite Fabricated Melt Processing at $1^{1500}{ }^{\circ} \mathrm{C}$ with $\mathrm{Ti} / \mathrm{TiO}_{2}$ buffer additions in $1 \% \mathrm{H}_{2}$ /balance Argon atmosphere Backscattered Electron Micrograph

Table 3-4. Cr/Al/Fe-Hollandite Fabricated by Melt Processing at $1500^{\circ} \mathrm{C}$ with $\mathrm{Ti} / \mathrm{TiO}_{2}$ buffer additions in $1 \% \mathrm{H}_{2}$ /balance Argon atmosphere -Summary of Elements and Crystalline Phases

(*Crystalline phases determined from XRD measurements and EDAX elemental analysis)

\begin{tabular}{|c|l|l||}
\hline Spot & \multicolumn{1}{|c||}{ Elements (Major, Minor) } & \multicolumn{1}{|c|}{ Crystalline Phases* } \\
\hline 1 & $\mathrm{O}, \mathrm{Al}$ & $\mathrm{Al}_{2} \mathrm{O}_{3}$ \\
\hline 2 & $\mathrm{O}, \mathrm{Fe},(\mathrm{Ti}, \mathrm{Al})$ & $\mathrm{Fe}_{2} \mathrm{O}_{3}$ \\
\hline 3 & $\mathrm{O}, \mathrm{Ti}, \mathrm{Al}, \mathrm{Cr}, \mathrm{Ba},(\mathrm{Cs}, \mathrm{Fe})$ & $\mathrm{Hollandite}$ \\
\hline 4 & $\mathrm{O}, \mathrm{Ti}, \mathrm{Zr}, \mathrm{Al}, \mathrm{Fe},(\mathrm{Cs}, \mathrm{Ca}, \mathrm{Ce}, \mathrm{Nd})$ & $\mathrm{CaZrTi} \mathrm{O}_{7}$ \\
\hline 5 & $\mathrm{O}, \mathrm{Ti}, \mathrm{Ca}, \mathrm{Nd}, \mathrm{Al},(\mathrm{Sc}, \mathrm{Sr}, \mathrm{Sm})$ & $\left(\mathrm{A}^{+3}{ }_{\mathrm{x}} \mathrm{B}^{+2}{ }_{1-\mathrm{x}}\right) \mathrm{TiO}_{3},\left(\mathrm{~A}^{+3}{ }_{\mathrm{x}} \mathrm{B}^{+2}{ }_{1-\mathrm{x}}\right)_{2} \mathrm{Ti}_{2} \mathrm{O}_{7}$ \\
\hline
\end{tabular}

\subsection{Vacuum Induction Melting}

Each composition was melted with and without a $\mathrm{Ti} / \mathrm{TiO}_{2}$ buffer in reducing conditions. Low oxygen levels resulting in reducing conditions were achieved by employing a vacuum induction melter operating at a pressure of $10^{-6}$ atm at $1500^{\circ} \mathrm{C}$ for 20 minutes. 


\subsubsection{Cr-Hollandite Multiphase Waste Form}

Figure 3-3 displays the microstructure and Table 3-5 tabulates the phases observed in $\mathrm{Cr}$-Hollandite with $\mathrm{Ti} / \mathrm{TiO}_{2}$ buffer fabricated by Vacuum Induction Melting at pressures $\sim 10^{-6}$ atm. The oxygen partial pressure of $\sim 10^{-6} \mathrm{~atm}$ during vacuum induction melting approximates the reducing conditions of an inert gas processing (pure Argon stream). The multiphase waste form showed a microstructure indicative of melting. The targeted crystalline phases were formed including hollandite, zirconolite, perovskite/pyrochlore along with residual $\mathrm{TiO}_{2}$ was observed. Hollandite formed in needle-like microstructures and residual $\mathrm{TiO}_{2}$ was found at the perovskite/titanate interface.

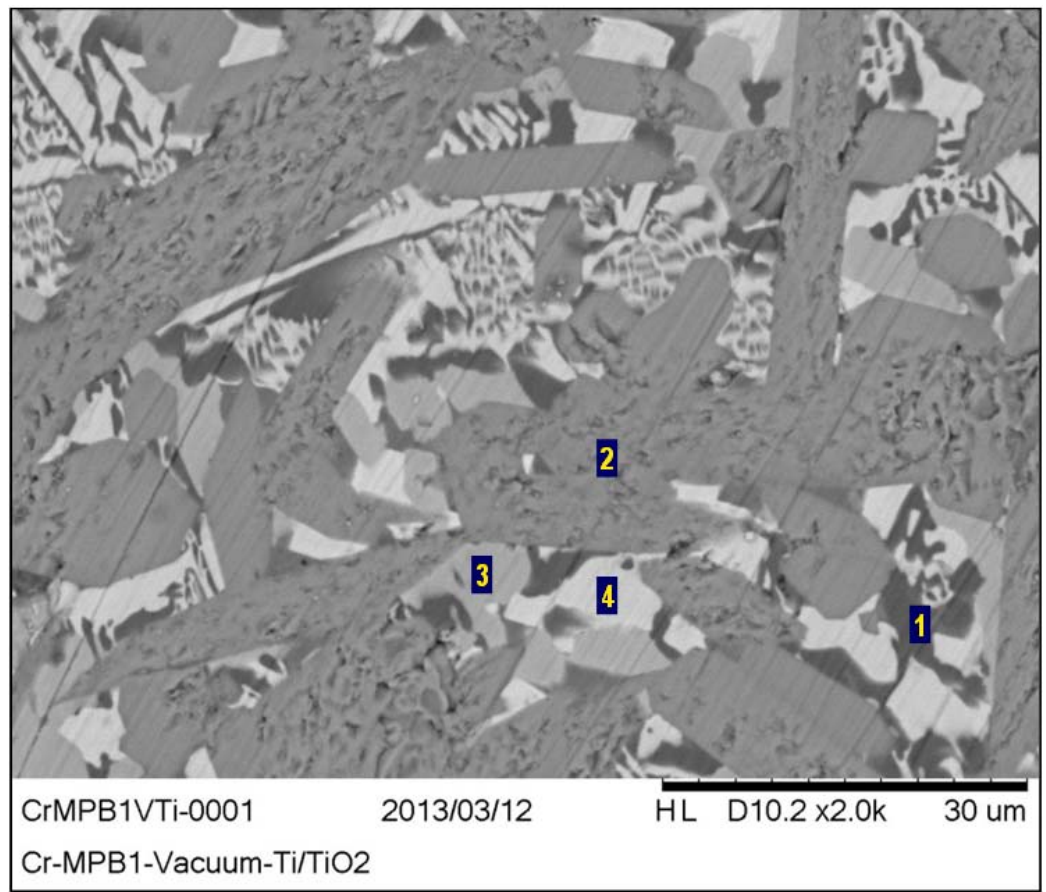

Figure 3-3. Cr-Hollandite Fabricated by Vacuum Induction Melting at $1500^{\circ} \mathrm{C}$ with $\mathrm{Ti} / \mathrm{TiO}_{2}$ bufferBackscattered Electron Micrograph

Table 3-5. Cr-Hollandite Fabricated by Vacuum Induction Melting at $1500^{\circ} \mathrm{C}$ with $\mathrm{Ti} / \mathrm{TiO}_{2}$ buffer Summary of Elements and Crystalline Phases $\left({ }^{*}\right.$ Crystalline phases determined from XRD measurements and EDAX elemental analysis)

\begin{tabular}{|c|l|l||}
\hline \hline Spot & \multicolumn{1}{|c|}{ Elements (Major, Minor) } & \multicolumn{1}{|c|}{ Crystalline Phases* } \\
\hline 1 & $\mathrm{O}, \mathrm{Ti},(\mathrm{Al}, \mathrm{Cr}, \mathrm{Zr}, \mathrm{Ba}, \mathrm{La}, \mathrm{Ca}, \mathrm{Cs})$ & $\mathrm{TiO}_{2}$ \\
\hline 2 & $\mathrm{O}, \mathrm{Ti}, \mathrm{Cr}, \mathrm{Ba},(\mathrm{Al}, \mathrm{Ca}, \mathrm{Zr}, \mathrm{Cs})$ & $\mathrm{Hollandite}$ \\
\hline 3 & $\mathrm{O}, \mathrm{Ti}, \mathrm{Zr},(\mathrm{Al}, \mathrm{Ca}, \mathrm{Cr}, \mathrm{Y}, \mathrm{La}, \mathrm{Ce}, \mathrm{Pr}, \mathrm{Nd}, \mathrm{Sm})$ & $\mathrm{CaZrTi}_{2} \mathrm{O}_{7}$ \\
\hline 4 & $\mathrm{O}, \mathrm{Ti}, \mathrm{Nd},(\mathrm{Ca}, \mathrm{Cr}, \mathrm{Sr}, \mathrm{Y}, \mathrm{Ba}, \mathrm{La}, \mathrm{Ce}, \mathrm{Pr}, \mathrm{Sm})$ & $\left(\mathrm{Al}^{3+}\right)_{2} \mathrm{TiO}_{5},\left(\mathrm{La}_{0.4} \mathrm{Ca}_{0.4} \mathrm{TiO}_{3}\right)$ \\
\hline
\end{tabular}

\subsubsection{Cr/Al/Fe Hollandite Multiphase Waste form}

Figure 3-4 displays the microstructure and Table 3-6 tabulates the phases observed in $\mathrm{Cr} / \mathrm{Al} / \mathrm{Fe}$ Hollandite with $\mathrm{Ti} / \mathrm{TiO}_{2}$ buffer fabricated by Vacuum Induction Melting at pressures $\sim 10^{-6} \mathrm{~atm}$. The multiphase waste form showed grain structure indicative of melting. The targeted crystalline phases were formed including hollandite, zirconolite, perovskite/pyrochlore along with residual $\mathrm{Al}_{2} \mathrm{O}_{3}$. In this sample, 
the hollandite exhibited a needle-like microstructure and residual $\mathrm{Al}_{2} \mathrm{O}_{3}$ was found adjacent to the hollandite phase.

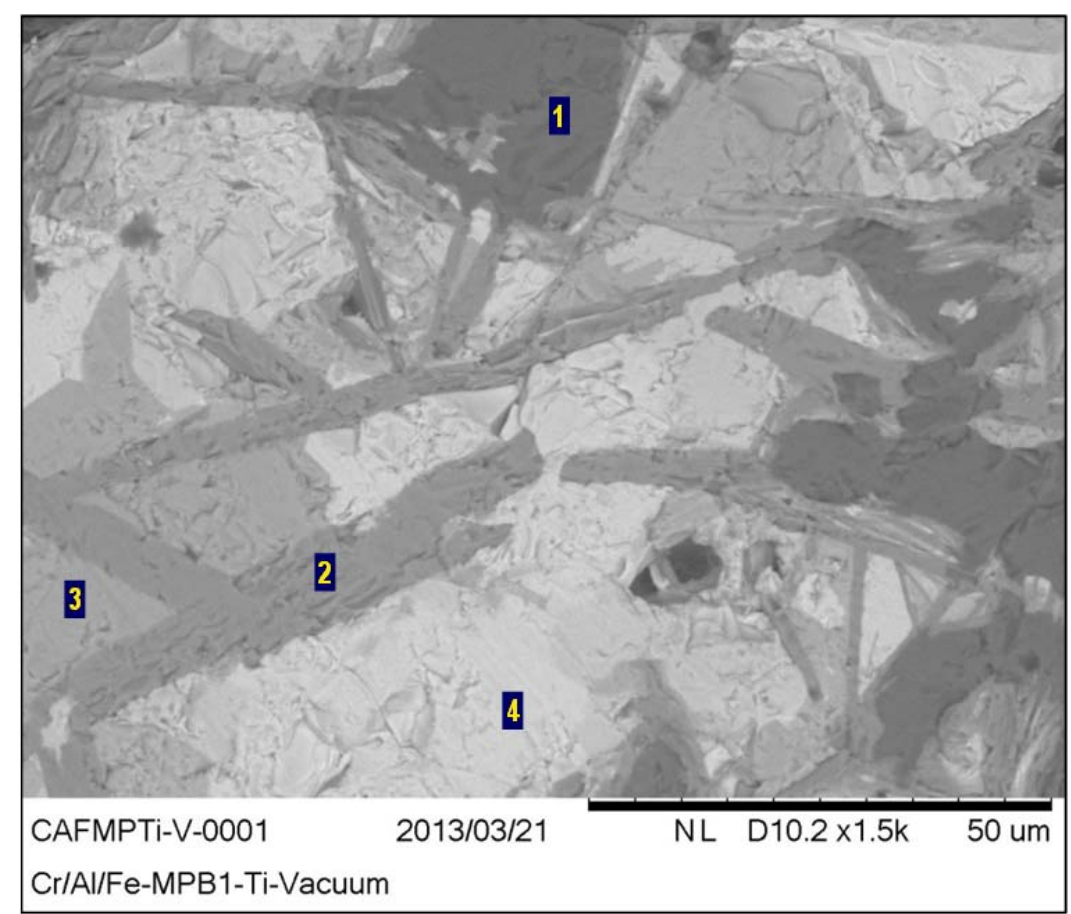

Figure 3-4. Cr/Al/Fe-Hollandite Fabricated by Vacuum Induction Melting at at $1500^{\circ} \mathrm{C}$ with $\mathrm{Ti} / \mathrm{TiO}_{2}$ buffer -Backscattered Electron Micrograph

Table 3-6. Cr/Al/Fe-Hollandite Fabricated by Vacuum Induction Melting at at $1500^{\circ} \mathrm{C}$ with $\mathrm{Ti} / \mathrm{TiO}_{2}$ buffer -Summary of Elements and Crystalline Phases (*Crystalline phases determined from XRD measurements and EDAX elemental analysis)

\begin{tabular}{|c|l|l|}
\hline Spot & \multicolumn{1}{|c|}{ Elements (Major, Minor) } & \multicolumn{1}{|c|}{ Crystalline Phases* } \\
\hline 1 & $\mathrm{O}, \mathrm{Al},(\mathrm{Ti}, \mathrm{Cr})$ & $\mathrm{Al}_{2} \mathrm{O}_{3}$ \\
\hline 2 & $\mathrm{O}, \mathrm{Ti}, \mathrm{Ba},(\mathrm{Al}, \mathrm{Cr}, \mathrm{Fe}, \mathrm{Cs}, \mathrm{Ce})$ & $\mathrm{Hollandite,}_{\mathrm{BaTiO}}$ \\
\hline 3 & $\mathrm{O}, \mathrm{Ti}, \mathrm{Zr},(\mathrm{Al}, \mathrm{Ca}, \mathrm{Fe}, \mathrm{Y}, \mathrm{Ce}, \mathrm{Nd}, \mathrm{Sm})$ & $\mathrm{CaZrTi}_{2} \mathrm{O}_{7}$ \\
\hline 4 & $\mathrm{O}, \mathrm{Al}, \mathrm{Ti},(\mathrm{Cr}, \mathrm{Fe}, \mathrm{Sr}, \mathrm{Ce}, \mathrm{Nd})$ & $\left(\mathrm{A}^{3+}\right)_{2} \mathrm{TiO}_{5}$ \\
\hline
\end{tabular}




\subsection{Spark Plasma Sintering (SPS)}

Spark Plasma Sintering (SPS) was conducted on a Dr. Sinter Model SPS 515S from Metals Processing Inc. Approximately $1 \mathrm{~g}$ of powder batch was mixed with a $\mathrm{Ti} / \mathrm{TiO}_{2}$ buffer and loaded in a graphite die for SPS processing at temperatures between 1080 and $1387^{\circ} \mathrm{C}$.

\subsubsection{Cr-Hollandite Multiphase Waste Form}

Figure 3-5 displays the microstructure and Table 3-7 tabulates the phases observed in $\mathrm{Cr}$-Hollandite with $\mathrm{Ti} / \mathrm{TiO}_{2}$ buffer fabricated by SPS at $1232^{\circ} \mathrm{C}$. The multiphase waste form showed a fine grain structure (110 micron grain size) expected from rapid sintering techniques. The targeted crystalline phases were formed including hollandite, zirconolite, perovskite/pyrochlore along a Mo containing metallic alloy. The phases were observed in round microstructures typical of solid state sintering as opposed to needle-like crystalline materials observed in the melt processed samples.

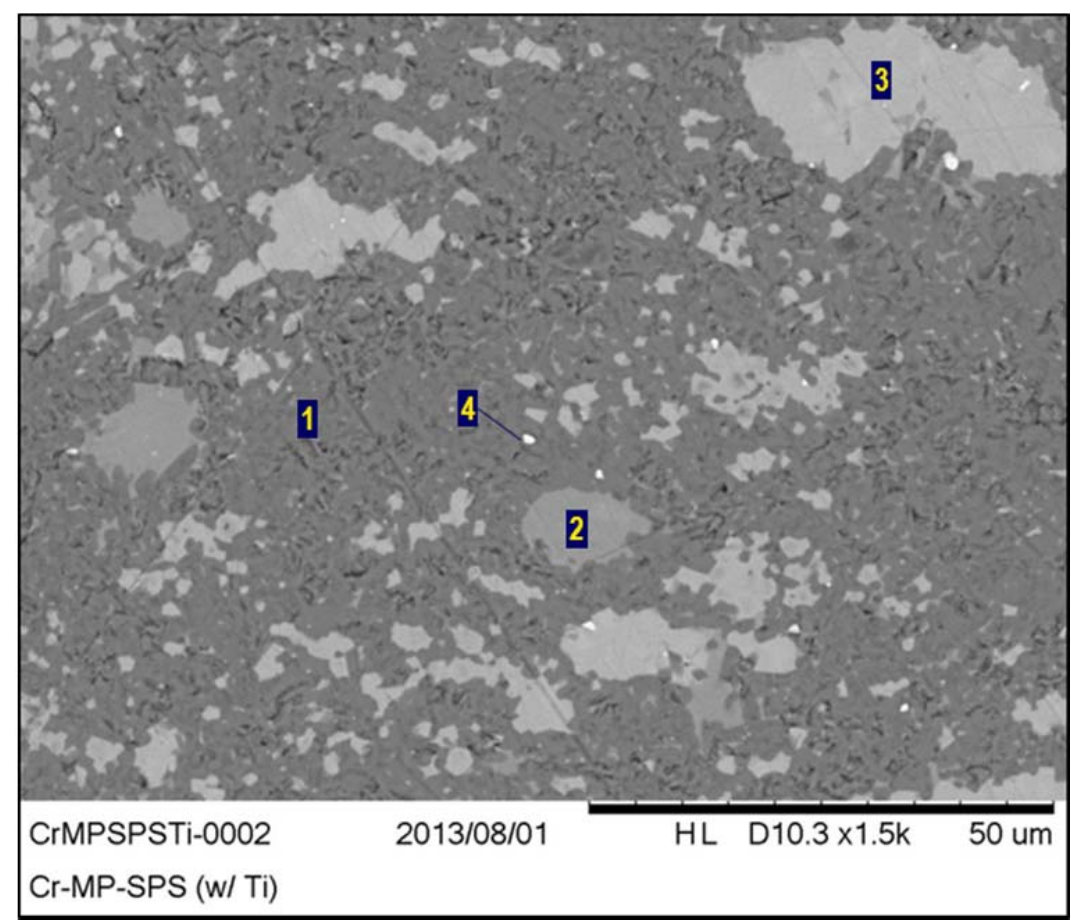

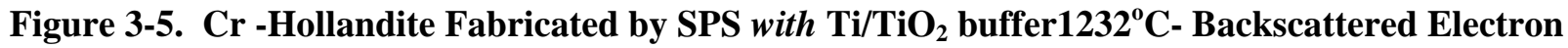
Micrograph

Table 3-7. Cr-Hollandite Fabricated by SPS with $\mathrm{Ti} / \mathrm{TiO}_{2}$ buffer at $1232^{\circ} \mathrm{C}$-Summary of Elements and Crystalline Phases (*Crystalline phases determined from XRD measurements and EDAX elemental analysis)

\begin{tabular}{|l|l|l||}
\hline Spot & \multicolumn{1}{|c|}{ Elements (Major, Minor) } & \multicolumn{1}{|c|}{ Crystalline Phases* } \\
\hline 1 & $\mathrm{O}, \mathrm{Ti}, \mathrm{Ba}, \mathrm{Fe}, \mathrm{Cr}, \mathrm{Al},(\mathrm{Cs}, \mathrm{Zr})$ & Hollandite \\
\hline 2 & $\mathrm{O}, \mathrm{Ti}, \mathrm{Zr}, \mathrm{Ca}$ & $\mathrm{CaZrTi}$ \\
2 & $\mathrm{O}_{7}$ \\
\hline 3 & $\mathrm{O}, \mathrm{Ti}, \mathrm{Nd}, \mathrm{Cr},(\mathrm{Zr}, \mathrm{Sr}, \mathrm{Y})$ & $\left(\mathrm{A}^{+3}{ }_{\mathrm{x}} \mathrm{B}_{1-\mathrm{x}}\right) \mathrm{TiO}_{3},\left(\mathrm{~A}^{+3}{ }_{\mathrm{x}} \mathrm{B}^{+2}{ }_{1-\mathrm{x}}\right)_{2} \mathrm{Ti}_{2} \mathrm{O}_{7}$ \\
\hline 4 & $\mathrm{Mo}$ & Metallic \\
\hline
\end{tabular}




\subsubsection{Cr/Al/Fe Hollandite Multiphase Waste form}

Figure 3-6 displays the microstructure and Table 3-8 tabulates the phases observed in $\mathrm{Cr} /$ $\mathrm{Al} / \mathrm{Fe}$-Hollandite with $\mathrm{Ti} / \mathrm{TiO}_{2}$ buffer fabricated by SPS at $1230^{\circ} \mathrm{C}$. The multiphase waste form showed a similar microstructure compared to the $\mathrm{Cr}$ analogue. The targeted crystalline phases were formed including hollandite, zirconolite, perovskite/pyrochlore along a Mo containing metallic alloy.

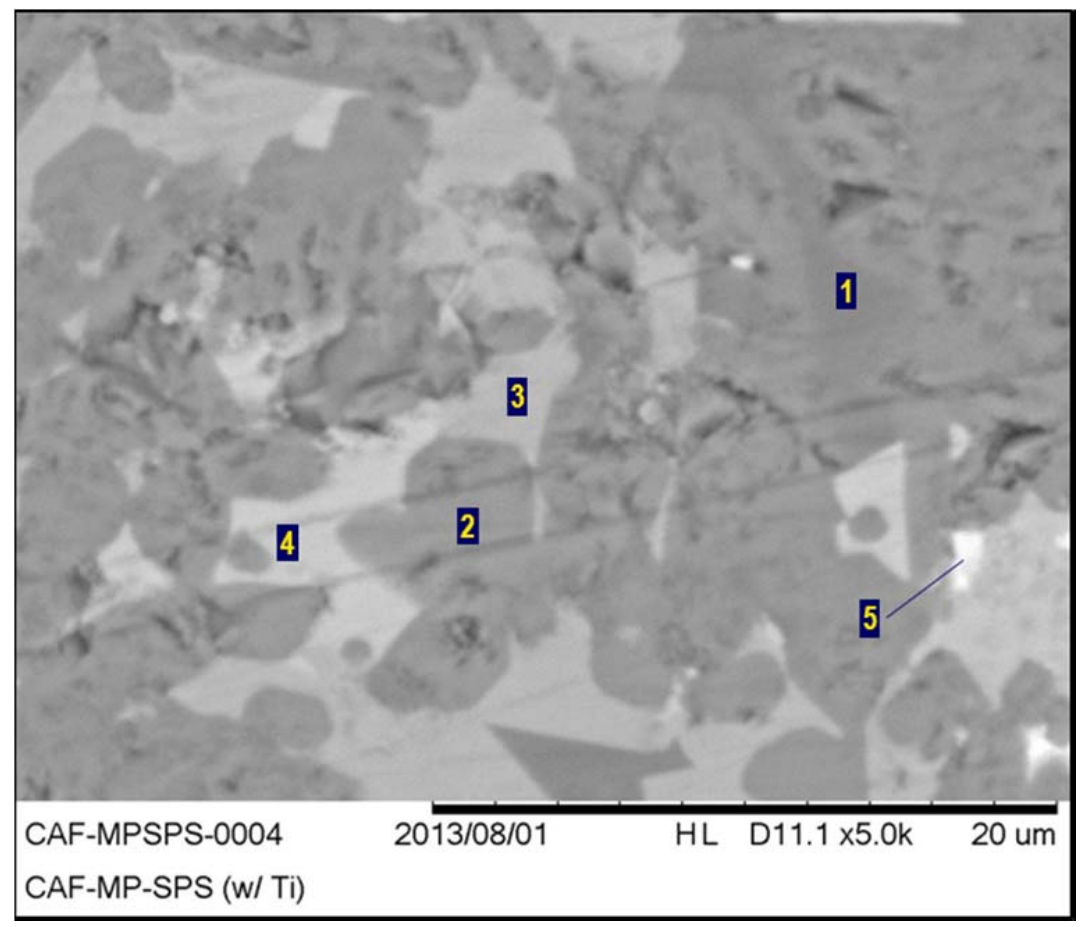

Figure 3-6. Cr/Al/Fe-Hollandite Fabricated by SPS with $\mathrm{Ti}^{-\mathrm{TiO}_{2}}$ buffer at $1230^{\circ} \mathrm{C}$ Backscattered Electron Micrograph

Table 3-8. $\mathrm{Cr} / \mathrm{Al} / \mathrm{Fe}-\mathrm{Hollandite} \mathrm{Fabricated} \mathrm{by} \mathrm{SPS} \mathrm{with} \mathrm{Ti} / \mathrm{TiO}_{2}$ buffer at $1230^{\circ} \mathrm{C}$-Summary of Elements and Crystalline Phases (*Crystalline phases determined from XRD measurements and EDAX elemental analysis)

\begin{tabular}{|c|l|l|}
\hline Spot & \multicolumn{1}{|c|}{ Elements (Major, Minor) } & \multicolumn{1}{|c|}{ Crystalline Phases* } \\
\hline 1,2 & $\mathrm{O}, \mathrm{Ti}, \mathrm{Ba}, \mathrm{Fe}, \mathrm{Cr}, \mathrm{Al},(\mathrm{Cs}, \mathrm{Zr})$ & Hollandite \\
\hline 3 & $\mathrm{O}, \mathrm{Ti}, \mathrm{Zr}, \mathrm{Ca},(\mathrm{Fe}, \mathrm{Nd})$ & $\left(\mathrm{A}^{+3}{ }_{\mathrm{B}} \mathrm{B}^{+2}{ }_{1-\mathrm{x}}\right) \mathrm{TiO}_{3},\left(\mathrm{~A}^{+3}{ }_{\mathrm{x}} \mathrm{B}^{+2}{ }_{1-\mathrm{x}}\right)_{2} \mathrm{Ti}_{2} \mathrm{O}_{7}$ \\
\hline 4 & $\mathrm{O}, \mathrm{Ti}, \mathrm{Nd}, \mathrm{Ca},(\mathrm{Sr}, \mathrm{Y})$ & $\mathrm{CaZrTi}_{2} \mathrm{O}_{7}$ \\
\hline 5 & $\mathrm{Te}(\mathrm{Mo})$ & Metallic \\
\hline
\end{tabular}

\subsection{Hot Pressing (HP)}

The hot pressing procedure consisted of an initial $10^{\circ} \mathrm{C} / \mathrm{min}$ ramp to a temperature of $1200^{\circ} \mathrm{C}$ where the sample was held for 2 hours followed by a decrease of the temperature to $1000^{\circ} \mathrm{C}$ in 15 minutes and finally shutting off the furnace and allowing the sample to cool to room temperature in approximately 2.5 hours. The pressure was maintained at $40+/-1 \mathrm{MPa}$ with nitrogen gas supplied at a flow rate of $40 \mathrm{ml} / \mathrm{min}$ during the hot press procedure. 


\subsubsection{Cr-Hollandite Multiphase Waste Form}

Figure 3-7 displays the microstructure and Table 3-9 tabulates the phases observed in $\mathrm{Cr}$ -Hollandite with $\mathrm{Ti} / \mathrm{TiO}_{2}$ buffer fabricated by $\mathrm{HP}$ at $1200^{\circ} \mathrm{C}$. The multiphase waste form showed a fine grain structure as compared to the melt processed samples. The targeted crystalline phases were formed including hollandite, zirconolite, perovskite/pyrochlore along with residual $\mathrm{TiO}_{2}$. Multiple titanates with distinct composition were observed.

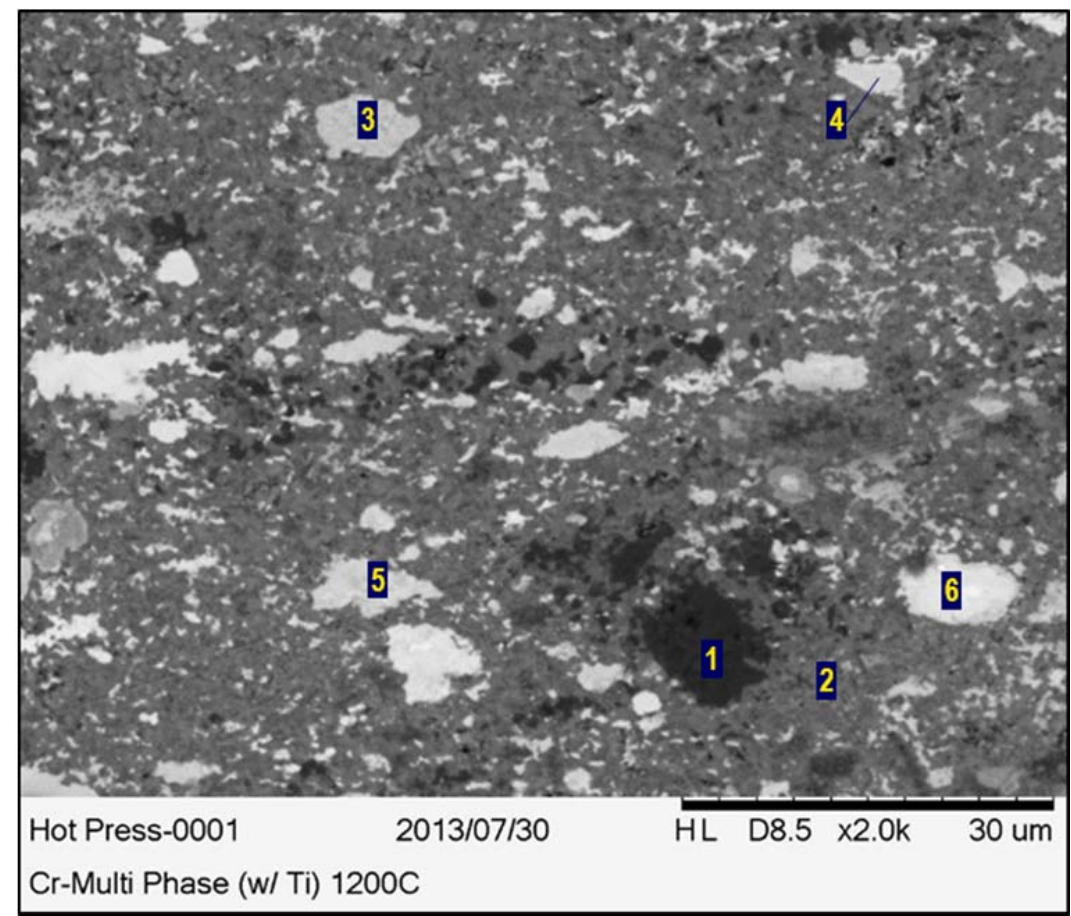

Figure 3-7. Cr-Hollandite Fabricated by $\mathrm{HP} 1200^{\circ} \mathrm{C}$ with $\mathrm{Ti} / \mathrm{TiO}_{2}$ buffer- Backscattered Electron Micrograph

Table 3-9. Cr-Hollandite Fabricated by $\mathrm{HP} 1200^{\circ} \mathrm{C}$ with $\mathrm{Ti} / \mathrm{TiO}_{2}$ buffer -Summary of Elements and Crystalline Phases (*Crystalline phases determined from XRD measurements and EDAX elemental analysis)

\begin{tabular}{|c|l|l||}
\hline Spot & Elements (Major, Minor) & \multicolumn{1}{c|}{ Crystalline Phases* } \\
\hline 1 & $\mathrm{O}, \mathrm{Ti}$ & $\mathrm{TiO}_{2}$ \\
\hline 2 & & $\mathrm{Hollandite}$ \\
\hline 3 & $\mathrm{O}, \mathrm{Ti}, \mathrm{Zr},(\mathrm{Ca}, \mathrm{Cr})$ & $\mathrm{CaZrTi} \mathrm{O}_{7}$ \\
\hline 4 & $\mathrm{O}, \mathrm{Ti}, \mathrm{Ce}$ & $\left(\mathrm{A}^{+3} \mathrm{~B}_{2}^{+2}{ }_{1-\mathrm{x}}\right) \mathrm{TiO}_{3},\left(\mathrm{~A}^{+3}{ }_{\mathrm{x}} \mathrm{B}^{+2}{ }_{1-\mathrm{x}}\right)_{2} \mathrm{Ti}_{2} \mathrm{O}_{7}$ \\
\hline 5 & $\mathrm{O}, \mathrm{Ti}, \mathrm{La}, \mathrm{Cr}$ & $\left(\mathrm{A}^{+3} \mathrm{~B}^{+2}{ }_{1-\mathrm{x}}\right) \mathrm{TiO}_{3},\left(\mathrm{~A}^{+3} \mathrm{~B}^{+2}{ }_{1-\mathrm{x}}\right)_{2} \mathrm{Ti}_{2} \mathrm{O}_{7}$ \\
\hline 6 & $\mathrm{O}, \mathrm{Ti}, \mathrm{Nd}, \mathrm{Pr},(\mathrm{Sr}, \mathrm{Zr})$ & $\left(\mathrm{A}^{+3}{ }_{\mathrm{x}} \mathrm{B}^{+2}{ }_{1-\mathrm{x}}\right) \mathrm{TiO}_{3},\left(\mathrm{~A}^{+3}{ }_{\mathrm{x}} \mathrm{B}^{+2}{ }_{1-\mathrm{x}}\right)_{2} \mathrm{Ti}_{2} \mathrm{O}_{7}$ \\
\hline
\end{tabular}

\subsubsection{Cr/Al/Fe Hollandite Multiphase Waste form}

Figure 3-8 displays the microstructure and Table 3-10 tabulates the phases observed in $\mathrm{Cr} / \mathrm{Al} / \mathrm{Fe}$ -Hollandite with $\mathrm{Ti} / \mathrm{TiO}_{2}$ buffer fabricated by $\mathrm{HP}$ at $1200^{\circ} \mathrm{C}$. The multiphase waste form a similar structure compared to the $\mathrm{Cr}$ analogue. A majority of the targeted crystalline phases were formed 
including hollandite, perovskite/pyrochlore along with residual $\mathrm{Al}_{2} \mathrm{O}_{3}$ and $\mathrm{TiO}_{2}$. Notably, the zirconolite phase was absent and multiple titanates with distinct composition were observed.

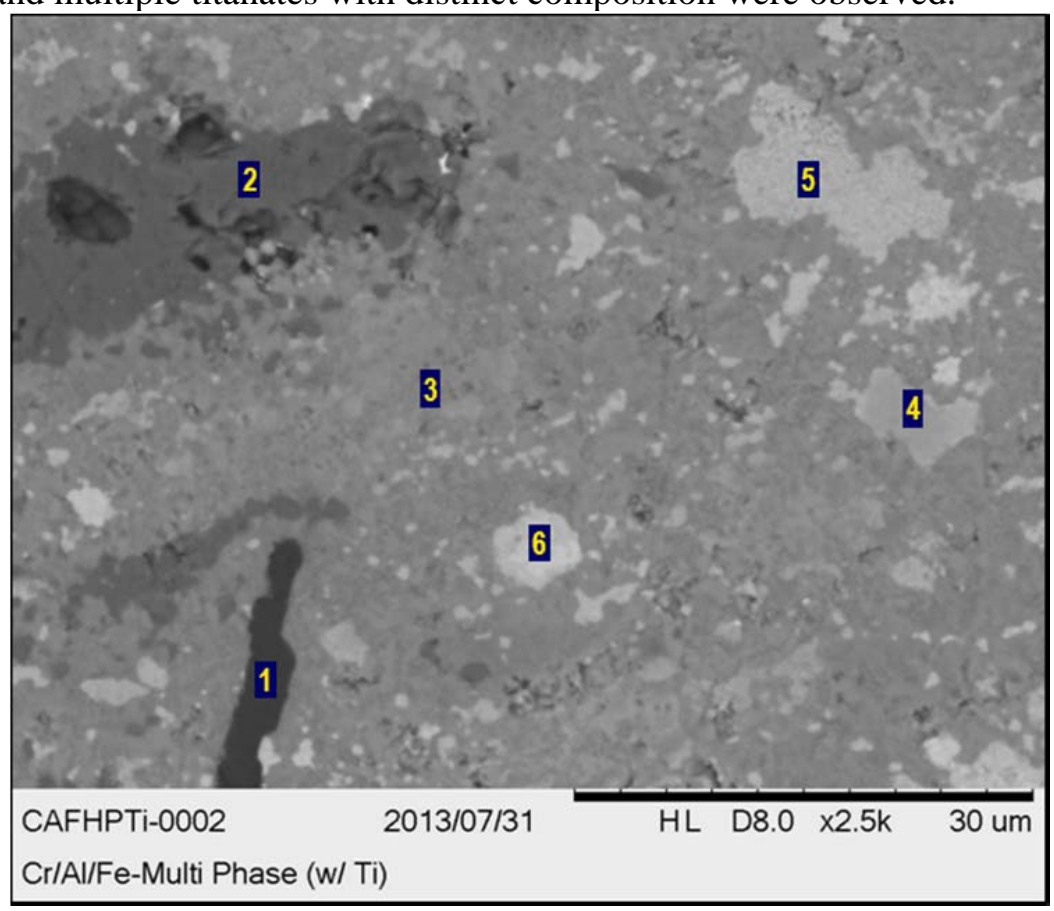

Figure 3-8. $\mathrm{Cr} / \mathrm{Al} / \mathrm{Fe}-\mathrm{Hollandite}$ Fabricated by $\mathrm{HP} \mathbf{1 2 0 0}^{\circ} \mathrm{C}$ with $\mathrm{Ti} / \mathrm{TiO}_{2}$ buffer Backscattered Electron Micrograph

Table 3-10. Cr/Al/Fe-Hollandite Fabricated by $\mathrm{HP} 1200^{\circ} \mathrm{C}$ with $\mathrm{Ti} / \mathrm{TiO}_{2}$ buffer -Summary of Elements and Crystalline Phases (*Crystalline phases determined from XRD measurements and EDAX elemental analysis)

\begin{tabular}{|c|l|l||}
\hline Spot & \multicolumn{1}{|c|}{ Elements (Major, Minor) } & \multicolumn{1}{|c|}{ Crystalline Phases* } \\
\hline 1 & $\mathrm{O}, \mathrm{Al}$ & $\mathrm{Al}_{2} \mathrm{O}_{3}$ \\
\hline 2 & $\mathrm{O}, \mathrm{Ti}$ & $\mathrm{TiO}_{2}$ \\
\hline 3 & $\mathrm{O}, \mathrm{Ti}, \mathrm{Ca}, \mathrm{Ba}, \mathrm{Fe}, \mathrm{Cr},(\mathrm{Nd}, \mathrm{Zr}, \mathrm{Cs}, \mathrm{Al})$ & $\mathrm{Hollandite}$ \\
\hline 4 & $\mathrm{O}, \mathrm{Ti}, \mathrm{Y},(\mathrm{Fe})$ & $\left(\mathrm{A}^{+3}\right)_{2} \mathrm{Ti}_{2} \mathrm{O}_{7}$ \\
\hline 5 & $\mathrm{O}, \mathrm{Ti}, \mathrm{Ce}, \mathrm{Nd}, \mathrm{Ba}$ & $\left(\mathrm{A}^{+3}{ }_{\mathrm{x}} \mathrm{B}^{+2}{ }_{1-\mathrm{x}}\right) \mathrm{TiO}_{3},\left(\mathrm{~A}^{+3}{ }_{\mathrm{x}} \mathrm{B}^{+2}{ }_{1-\mathrm{x}}\right)_{2} \mathrm{Ti}_{2} \mathrm{O}_{7}$ \\
\hline 6 & $\mathrm{O}, \mathrm{Ti}, \mathrm{Zr}, \mathrm{Ca},(\mathrm{Fe}, \mathrm{Nd})$ & $\left(\mathrm{A}^{+3}{ }_{\mathrm{x}} \mathrm{B}^{+2}{ }_{1-\mathrm{x}}\right) \mathrm{TiO}_{3},\left(\mathrm{~A}^{+3}{ }_{\mathrm{x}} \mathrm{B}^{+2}{ }_{1-\mathrm{x}}\right)_{2} \mathrm{Ti}_{2} \mathrm{O}_{7}$ \\
\hline
\end{tabular}

Table 3-11 presents a summary of the phase formation as a function of composition and processing conditions for multiphase waste forms fabricated in this study. In general, both compositions (Cr-MPB and $\mathrm{Cr} / \mathrm{Al} / \mathrm{Fe}-\mathrm{MPB}$ ) formed the major targeted phases under all processing conditions including Cscontaining hollandite. The pure Cr-analogue displayed some regions with incomplete melting and may need higher temperatures $\left(1600^{\circ} \mathrm{C}\right)$ for melt processing. A metallic Mo containing alloy which was encapsulated in oxide phases was observed in SPS and HP samples using solid state sintering, while this phase was mostly absent in melt processed samples. An examination of crystallized ceramic material sampled from the crucible bottom as well as examination of the alumina crucible area in contact with the melt revealed Mo metal penetration into the alumina grain boundary regions of the crucible indicating the metal phases may have sank to the bottom during melt processing. 
Table 3-11. Multiphase Characterization Summary ${ }^{\mathrm{a}}$

\begin{tabular}{|c|c|c|c|c|c|}
\hline \multirow[b]{2}{*}{ Short Identifiera } & \multicolumn{4}{|c|}{ Phases } & \multirow[b]{2}{*}{$\begin{array}{l}\text { Processing } \\
\text { Conditions }\end{array}$} \\
\hline & $\begin{array}{l}\text { Cs-Hollandite } \\
\left(\mathrm{Ba}_{x} \mathrm{Cs}_{y}\right)(\mathrm{Ti}, \mathrm{Al})^{+3}{ }_{2 x+y}\left(\mathrm{Ti}^{+}\right. \\
\left.{ }_{88-2 x-y}\right) \mathrm{O}_{16}\end{array}$ & $\begin{array}{l}\text { (4+) Zirconolite } \\
\text { CaZrTit }\end{array}$ & $\begin{array}{l}(2+/ 3+) \text { Titanate (i.e. } \\
\text { Pyroclore I Perovskite) } \\
\left(\mathrm{A}^{2+}\right) \mathrm{TiO}_{3} ;\left(\mathrm{A}^{3+}\right)_{2} \mathrm{Ti}_{2} \mathrm{O}_{7}\end{array}$ & Other & \\
\hline \multicolumn{6}{|l|}{ Melt Processing } \\
\hline Cr-MPB1A & $x$ & $x$ & $x$ & $\mathrm{TiO}_{2}$ & Air \\
\hline Cr-MPB1A-Ti & $x$ & $x$ & $x$ & $\mathrm{TiO}_{2}$ & Air w/Ti-TiO 2 \\
\hline Cr-MPB1R & $x$ & $x$ & $x$ & & $1 \% \mathrm{H}_{2}$ \\
\hline Cr-MPB1R-Ti & $x$ & $x$ & $x$ & $\mathrm{TiO}_{2}$ & $1 \% \mathrm{H}_{2} \mathrm{w} / \mathrm{Ti}-\mathrm{TiO}_{2}$ \\
\hline CAF-MPB1A & $x$ & $x$ & $x$ & & Air \\
\hline CAF-MPB1A-Ti & $x$ & & $x$ & $\mathrm{TiO}_{2}$ & Air w/Ti-TiO 2 \\
\hline CAF-MPB1R & $x$ & & $x$ & $\mathrm{BaFe}_{12} \mathrm{O}_{19}$ & $1 \% \mathrm{H}_{2}$ \\
\hline CAF-MPB1R-Ti & $x$ & $x$ & $x$ & $\mathrm{~A}^{+3} \mathrm{TiO}_{5}$ & $1 \% \mathrm{H}_{2} \mathrm{w} / \mathrm{Ti}-\mathrm{TiO}_{2}$ \\
\hline \multicolumn{6}{|c|}{ Vacuum Induction Melting } \\
\hline Cr-MPB1V & $x$ & & $x$ & & Vacuum \\
\hline Cr-MPB1V-Ti & $x$ & $x$ & $x$ & & Vacuum w/Ti-TiO 2 \\
\hline CAF-MPB1V & $x$ & & $x$ & $\begin{array}{l}\mathrm{Al}_{2} \mathrm{O}_{3}, \quad \mathrm{BaFe}_{12} \mathrm{O}_{19} \\
\mathrm{Ca}_{3} \mathrm{Ti}_{8} \mathrm{Al}_{12} \mathrm{O}_{37}\end{array}$ & Vacuum \\
\hline CAF-MPB1V-Ti & $x$ & $x$ & $x$ & $\mathrm{Al}_{2} \mathrm{O}_{3}$ & Vacuum w/Ti-TiO ${ }_{2}$ \\
\hline \multicolumn{6}{|c|}{ Spark Plasma Sintering (SPS) } \\
\hline Cr-MP-SPS-1281 & $x$ & $x$ & $x$ & & $1281^{\circ} \mathrm{C}$ \\
\hline Cr-MP-SPS-1387 & $x$ & & $x$ & & $1387^{\circ} \mathrm{C}$ \\
\hline Cr-MP-SPS-Ti-1080 & $x$ & $x$ & $x$ & $\mathrm{TiO}_{2}, \mathrm{Cr}_{2} \mathrm{O}_{3}$ & $1080^{\circ} \mathrm{Cw} / \mathrm{Ti}^{-\mathrm{TiO}_{2}}$ \\
\hline Cr-MP-SPS-Ti-1232 & $x$ & $x$ & $x$ & & $1232^{\circ} \mathrm{C} \mathrm{w} / \mathrm{Ti}^{-\mathrm{TiO}_{2}}$ \\
\hline CAF-MP-SPS-1230 & $x$ & $x$ & $x$ & & $1230^{\circ} \mathrm{C}$ \\
\hline CAF-MP-SPS-1350 & $x$ & $x$ & $x$ & & $1350^{\circ} \mathrm{C}$ \\
\hline CAF-MP-SPS-Ti-1200 & $x$ & $x$ & $x$ & & $1200^{\circ} \mathrm{C} \mathrm{w} / \mathrm{Ti}^{-\mathrm{TiO}_{2}}$ \\
\hline CAF-MP-SPS-Ti-1230 & $x$ & $x$ & $x$ & & $1230^{\circ} \mathrm{C} \mathrm{w} / \mathrm{Ti}^{-\mathrm{TiO}_{2}}$ \\
\hline \multicolumn{6}{|l|}{ Hot Pressing } \\
\hline Cr-MP-HP & $x$ & $x$ & $x$ & $\mathrm{Cr}_{2} \mathrm{O}_{3}, \mathrm{ZrO}_{2}$ & $\mathrm{~N}_{2}, 1200^{\circ} \mathrm{C}$ \\
\hline Cr-MP-HP-Ti & $x$ & $x$ & $x$ & $\mathrm{Cr}_{2} \mathrm{O}_{3}, \mathrm{ZrO}_{2}$ & $\mathrm{~N}_{2}, 1200^{\circ} \mathrm{C}$, w/Ti-TiO 2 \\
\hline CAF-MP-HP & $x$ & $x$ & $x$ & & $\mathrm{~N}_{2}, 1200^{\circ} \mathrm{C}$ \\
\hline CAF-MP-HP-Ti & $x$ & $x$ & $x$ & $\mathrm{TiO}_{2}$ & $\mathrm{~N}_{2}, 1200^{\circ} \mathrm{C}$, w/Ti-TiO 2 \\
\hline
\end{tabular}

Melt processed samples exhibited larger grain sizes ( 50-200 microns) with irregular, needle-like hollandite grains and large voids (> 10 microns). SPS and HP microstructures exhibited fine grain size $(\sim$

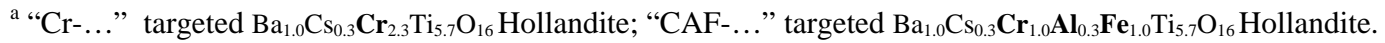

b The A site in these titanate structures will accommodate a wide variety of species including alkaline and rare-earths. Additionally, the A site is substitutional in many compounds and will be mixed. More general formula include $\left(\mathrm{A}^{+3}{ }_{x} \mathrm{~B}^{+2}{ }_{1-\mathrm{x}}\right) \mathrm{TiO}_{3}$, $\left(\mathrm{A}^{+3}{ }_{\mathrm{X}} \mathrm{B}^{+2}{ }_{1-\mathrm{x}}\right)_{2} \mathrm{Ti}_{2} \mathrm{O}_{7}$, etc. where $\mathrm{A}$ and $\mathrm{B}$ are tri- and di- valent species in the waste such as Ce, Nd, Pr, La, Ba, Y, Sr, etc. 
10 micron) with smaller pores ( 1micron) distributed throughout the microstructure. A detailed microstructural study of one composition ( $\mathrm{Cr} / \mathrm{Al} / \mathrm{Fe}-$ Multiphase) with $\mathrm{Ti} / \mathrm{TiO}_{2}$ buffer across a wide variety of redox and processing conditions is presented in the following section.

\section{DISCUSSION}

There have been several comparative studies of crystalline ceramic waste forms produced by hot pressing and inductive melting.[7, 11] These prior studies have indicated that the specimens in general exhibited similar mineral compositions, with the exception of melted ceramics showing evidence of molybdate phases due to air processing with Mo containing waste streams. A major objective of this work was aimed at varying the composition and processing conditions in order to mitigate Cs-Mo molybdate phase formation. In addition, there was particular interest regarding differences in phase formation, elemental partitioning and microstructural variation as a function of waste form composition and processing conditions. In this study, common microstructural differences between samples processed by a melt and crystallization route and solid state sintering routes include an order of magnitude increase in grain size with melted ceramics along with an increase in porosity. Figure 4-1 displays the microstructure and Table 4-1 tabulates the phases observed Single Phase Hollandite with a $\mathrm{Ti} / \mathrm{TiO}_{2}$ buffer fabricated i) melt processing in air at $1500^{\circ} \mathrm{C}$, ii) melt processing in $1 \% \mathrm{H}_{2}$ balance Argon at $1500^{\circ} \mathrm{C}$, iii) $\mathrm{HP}$ at $1200^{\circ} \mathrm{C}$ and iv) SPS at $1230^{\circ} \mathrm{C}$.

Firstly, significant Cs incorporation into the hollandite structure was observed via a melt processing route. The sample melt processed in air exhibited regions where incomplete melting occurred, most likely $\mathrm{Cr}$ rich regions which demonstrated this behavior in pure Cr-Hollandite analogues. The sample melt processed in hydrogen exhibited less of these incomplete melting regions. In addition to hollandite, a secondary Cs-phase $\mathrm{CsAlTiO}_{4}$ was observed in samples melt processed in air and $1 \% \mathrm{H}_{2}$. Additional secondary phases associated with Fe-Ti were observed when melt processed under hydrogen gas. SPS and HP samples also showed evidence of secondary phases associated with Fe as well as metal inclusions. In general the single phase hollandite samples that were melt processed possessed both larger grain sizes and larger pores than the SPS and HP samples. 

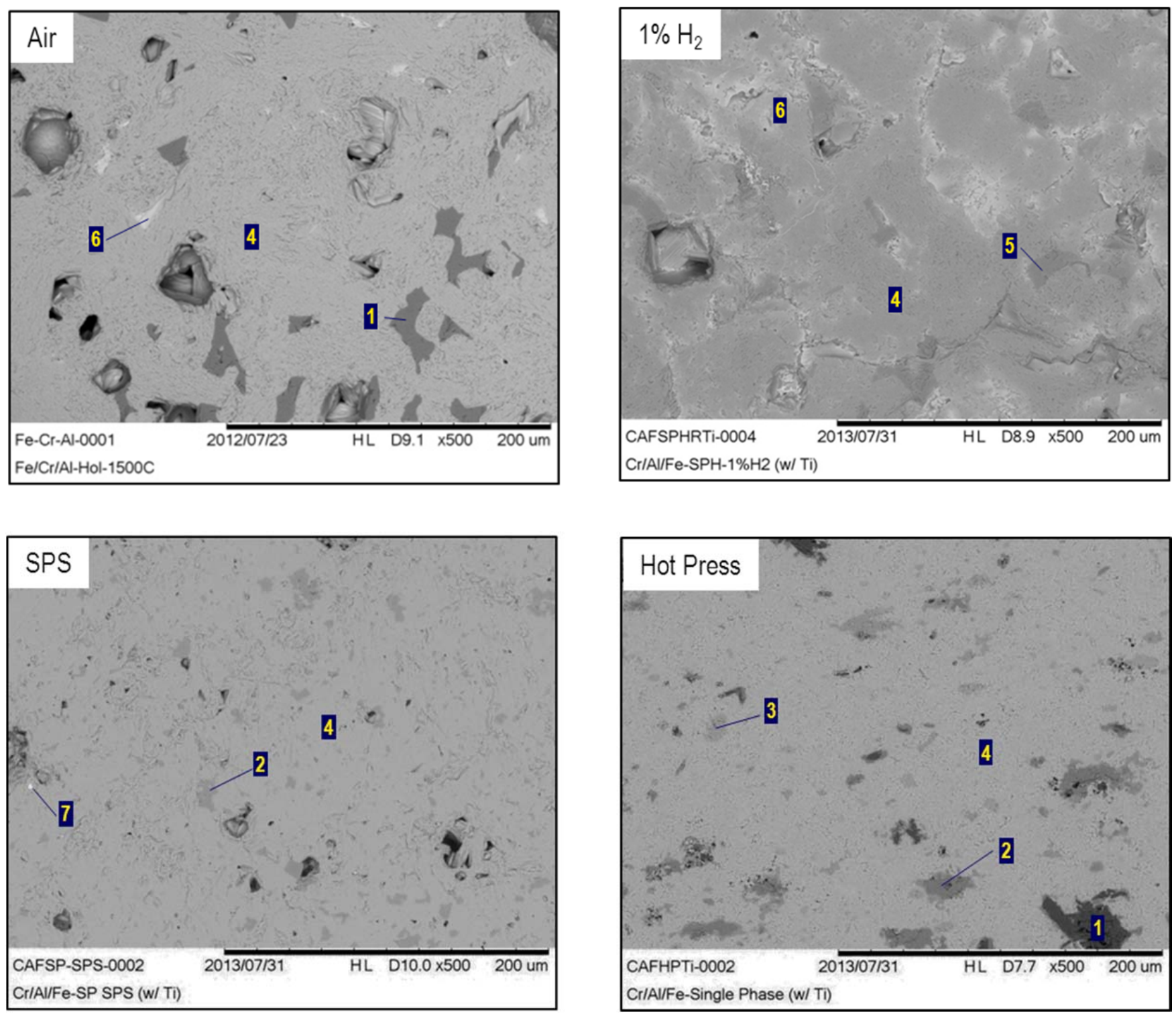

Figure 4-1. Single Phase Hollandite $\mathrm{Cr} / \mathrm{Al} / \mathrm{Fe}$ with $\mathrm{Ti} / \mathrm{TiO}_{2}$ Processing Comparison- Backscattered Electron Micrograph. (Air=Melting $1500^{\circ} \mathrm{C}$ in Air, $1 \% \mathrm{H}_{2}=$ Melting $1500^{\circ} \mathrm{C}$ in $1 \% \mathrm{H}_{2}$ balance Argon gas, SPS $=\mathrm{SPS}$ at $1230^{\circ} \mathrm{C}, \mathrm{HP}=\mathrm{HP}$ at $1200^{\circ} \mathrm{C}$ at $40 \mathrm{MPa}$ )

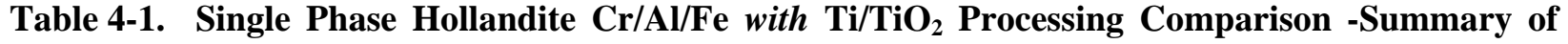
Elements and Crystalline Phases (*Crystalline phases determined from XRD measurements and EDAX elemental analysis)

\begin{tabular}{|c|l|l|}
\hline Spot & \multicolumn{1}{|c|}{ Major Elements } & \multicolumn{1}{c|}{ Crystalline Phases* } \\
\hline 1 & $\mathrm{O}, \mathrm{Ti}$ & $\mathrm{TiO}_{2}$ \\
\hline 2 & $\mathrm{O}, \mathrm{Fe}, \mathrm{Al}$ & $\mathrm{FeAl}_{2} \mathrm{O}_{4}$ \\
\hline 3 & $\mathrm{O}, \mathrm{Fe}$ & $\mathrm{Fe}_{2} \mathrm{O}_{3}, \mathrm{FeO}$ \\
\hline 4 & $\mathrm{O}, \mathrm{Ti}, \mathrm{Ba},(\mathrm{Cr}, \mathrm{Al}, \mathrm{Fe}, \mathrm{Cs})$ & $\mathrm{Holllandite}$ \\
\hline 5 & $\mathrm{O}, \mathrm{Ti}, \mathrm{Fe}$ & Titanate \\
\hline 6 & $\mathrm{O}, \mathrm{Cs}, \mathrm{Al},(\mathrm{Ti}, \mathrm{Si})$ & $\mathrm{CsAlTiO}_{4}$ \\
\hline 7 & $\mathrm{Fe}$ & Metallic \\
\hline
\end{tabular}


Figure 4-2 displays the microstructure and Table 4-2 tabulates the phases observed in Multiphase Waste Form $\mathrm{Cr} / \mathrm{Al} / \mathrm{Fe}$ Hollandite with a $\mathrm{Ti} / \mathrm{TiO}_{2}$ buffer fabricated i) melt processing in air at $1500^{\circ} \mathrm{C}$, ii) melt processing in $1 \% \mathrm{H}_{2}$ balance Argon at $1500^{\circ} \mathrm{C}$, iii) $\mathrm{HP}$ at $1200^{\circ} \mathrm{C}$ and iv) SPS at $1230^{\circ} \mathrm{C}$. Several differences between samples were observed with regards to phase formation, grain size and microstructure and elemental partitioning. Similar to the observation in single phase systems, the sample melt processed in air was not completely melted (more refractory $\mathrm{Cr}$ rich regions). Due to the incomplete melting, metallic species were incorporated into the microstructure when processed in air, but were absent from the bulk microstructure when processed under hydrogen.
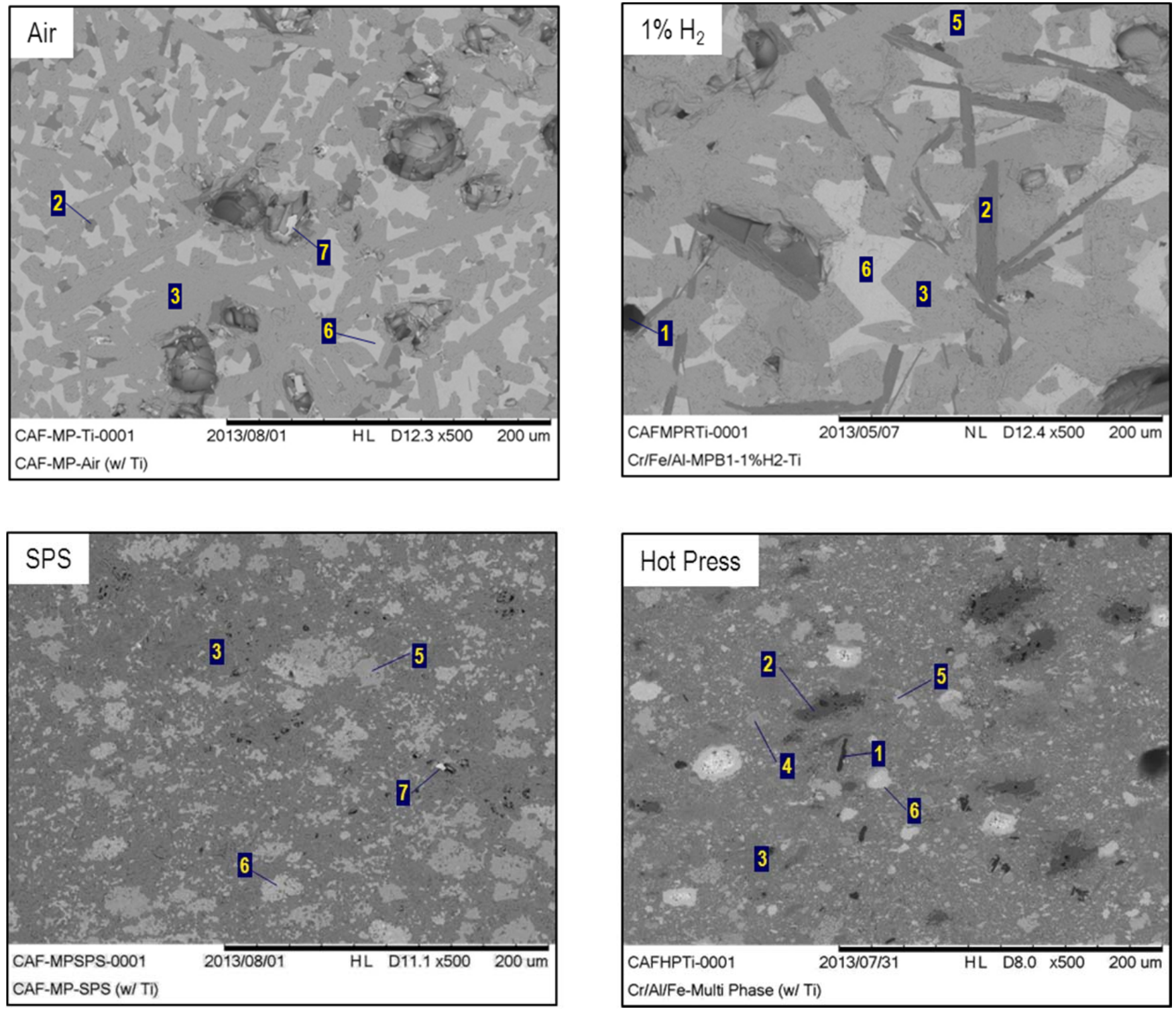

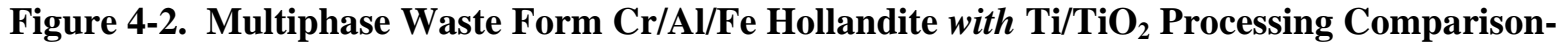
Backscattered Electron Micrograph 
Table 4-2. Multiphase Waste Form $\mathrm{Cr} / \mathrm{Al} / \mathrm{Fe}$ Hollandite with $\mathrm{Ti} / \mathrm{TiO}_{2}$ Processing Comparison Summary of Elements and Crystalline Phases (*Crystalline phases determined from XRD measurements and EDAX elemental analysis)

\begin{tabular}{|c|l|l|}
\hline Spot & \multicolumn{1}{|c|}{ Elements (Major, Minor) } & \multicolumn{1}{|c|}{ Crystalline Phases* } \\
\hline 1 & $\mathrm{O}, \mathrm{Al}$ & $\mathrm{Al}_{2} \mathrm{O}_{3}$ \\
\hline 2 & $\mathrm{O}, \mathrm{Ti}$ & $\mathrm{TiO}_{2}$ \\
\hline 3 & $\mathrm{O}, \mathrm{Ti}, \mathrm{Ca}, \mathrm{Ba}, \mathrm{Fe}, \mathrm{Cr},(\mathrm{Nd}, \mathrm{Zr}, \mathrm{Cs}, \mathrm{Al})$ & $\mathrm{Hollandite}^{+3}$ \\
\hline 4 & $\mathrm{O}, \mathrm{Ti}, \mathrm{Y},(\mathrm{Fe})$ & $\left(\mathrm{A}^{+3}\right)_{2} \mathrm{Ti}_{2} \mathrm{O}_{7}$ \\
\hline 5 & $\mathrm{O}, \mathrm{Ti}, \mathrm{Zr}, \mathrm{Ca},(\mathrm{Fe}, \mathrm{Nd})$ & $\mathrm{CaZrTi}_{2} \mathrm{O}_{7}$ \\
\hline 6 & $\mathrm{O}, \mathrm{Ti}, \mathrm{Ce}, \mathrm{Nd}, \mathrm{Pr}, \mathrm{La}, \mathrm{Y},(\mathrm{Ba}, \mathrm{Fe}, \mathrm{Al}, \mathrm{Cr})$ & $\left(\mathrm{A}_{\mathrm{x}}^{+3} \mathrm{~B}_{1-\mathrm{x}}^{+2} \mathrm{TiO}_{3},\left(\mathrm{~A}_{\mathrm{x}}^{+3} \mathrm{~B}_{1-\mathrm{x}}^{+2}\right)_{2} \mathrm{Ti}_{2} \mathrm{O}_{7}\right.$ \\
\hline 7 & $\mathrm{Mo}$ & Metallic \\
\hline
\end{tabular}

Melting of the sample was enhanced when processed under reducing gas and a metallic alloy containing Mo was observed in the bottom of the alumina crucible. Enhanced melting resulted in larger grain size for the samples processed under hydrogen gas as compared to those melted in air. Samples melt processed in air exhibited the targeted phase with the exception of zirconolite. Samples melt processed in hydrogen exhibited the targeted phases of hollandite, perovskite/pyrochlore, zirconolite with residual $\mathrm{TiO}_{2}$ and $\mathrm{Al}_{2} \mathrm{O}_{3}$.

The solid state sintering routes SPS and HP also demonstrated formation of the targeted phases. Hollandite, pervoskite/pyrochlore, zirconolite, metallic alloy and $\mathrm{TiO}_{2}$ and $\mathrm{Al}_{2} \mathrm{O}_{3}$ were observed distributed in a network of fine grains with small residual pores. The titanate phases that incorporate $\mathrm{M}^{+3}$ rare earth elements were observed to be distinct titanate phases $\left(\mathrm{Nd}_{2} \mathrm{Ti}_{2} \mathrm{O}_{7}\right)$ with less degree of substitution as compared to the more homogeneous melt processed samples where a high degree of substitution and variation of composition within grains was observed. In general, our observations corroborate similar reports of melt processed versus solid state sintered waste forms in the literature showing that melt processed samples formed similar phases, however had larger grain sized along with large voids associated with the melt process; SPS and HP samples exhibited finer grain size with smaller voids. Metallic alloys were observed in the bulk of the sample for SPS and HP samples, but were found at the bottom of the crucible in melt processed trials.

\section{RECOMMENDATIONS and PATH FORWARD}

This work has demonstrated that waste streams of interest to the FCR\&D program can be incorporated into crystalline ceramic waste forms by a melt and crystallization process. The targeted phases of hollandite, perovskite/pyrochlore, and zirconolite were similarly formed by a melt process as well as solid state sintering alternatives such as Hot Pressing and Spark Plasma Sintering. The principal differences between the synthesis procedures were the size of the voids (larger with melt process), grain size (order of magnitude larger for melt as compared to solid state processes), and ability to incorporate metallic alloys into the oxide matrix (Mo alloy sank to bottom of melt and crystallization process). The use of solid state buffer $\mathrm{Ti} / \mathrm{TiO}_{2}$ seems especially useful in promoting $\mathrm{Cs}$ incorporation into the hollandite phase and is recommended for use in subsequent melt processing trials. In fact, additives of Ti metal have been used to improve the electrical conductivity of powder batches in Cold Crucible Induction Melter trials and therefore serve a dual use. The two compositions studied in this report $\mathrm{Cr}$ and $\mathrm{Cr} / \mathrm{Al} / \mathrm{Fe}$ present a tradeoff between better phase formation- Cs incorporation into hollandite phase with less secondary phases 
present $(\mathrm{Cr})$ and the higher temperatures required to completely melt these more refractory compositions (estimated $\sim 1600^{\circ} \mathrm{C}$ ).

Results presented in Figure 4-2 of multiphase waste forms based on $\mathrm{Cr} / \mathrm{Al} / \mathrm{Fe}$-Hollandite indicate that these samples show similar phase formation when processed in air and $1 \% \mathrm{H}_{2}$ gas environments. The principal difference being the larger grain size due to enhanced melting in reducing gas environments. These results indicate that for a first melter trial, the targeted phases can be formed in air by utilizing $\mathrm{Ti} / \mathrm{TiO}_{2}$ additives which aid phase formation and improve the electrical conductivity. Ultimately, a melter run in reducing gas environments would be beneficial to study differences in phase formation and elemental partitioning. The electrical resistivity of SYNROC compositions has been previously measured to be on the order of $1 \mathrm{ohm} * \mathrm{~cm}$ at temperatures near $1500^{\circ} \mathrm{C}$ which was acceptable for CCIM processing demonstrations.[23] The electrical resistivity and viscosity of SRNL compositions of interest for FCR\&D program should be studied as a function of temperature in preparation for a potential CCIM melter test in FY14. 


\section{REFERENCES}

1. Waste Forms Technology and Performance Final Report by National Research Council of the National Academies ISBN-10: 0-309-18733-8. Waste Forms Technology and Performance Final Report by National Research Council of the National Academies ISBN-10: 0-309-18733-8, 2011.

2. Ringwood, A.E., et al., IMMOBILIZATION OF HIGH-LEVEL NUCLEAR-REACTOR WASTES IN SYNROC. Nature, 1979. 278(5701): p. 219-223.

3. Ringwood, A.E., et al., SYNROC PROCESS - GEOCHEMICAL APPROACH TO NUCLEAR WASTE IMMOBILIZATION. Geochemical Journal, 1979. 13(4): p. 141-165.

4. Perera, D.S., et al., Application of Crystal Chemistry in the Development of Radioactive Wasteforms. Advances in Technology of Materials and Materials Processing, 2004. 6(2): p. 214217.

5. Stefanovsky, S.V., et al., Inductive cold crucible melting of actinide-bearing murataite-based ceramics. Journal of Alloys and Compounds, 2007. 444: p. 438-442.

6. Demine, A.V., et al., High Level Waste Solidification Using a Cold Crucible Induction Melter. Mater. Res. Soc. Symp. Proc., 2001. 663: p. 27-34.

7. Advocat, T., et al., Alteration of Cold Crucible Melter Titanate-based Ceramics: Comparison with Hot-Pressed Titanate-based Ceramic. Mater. Res. Soc. Symp. Proc., 1997. 465: p. 355-362

8. Leturcq, G., et al., Solubility Study of Ti Zr-based Ceramics Designed to Immobilize Long-lived Radionuclides. American Mineralogist, 2001. 86(7-8): p. 871-880.

9. Brinkman, K., et al., Crystalline Ceramic Waste Forms: Reference Formulation Report Report SRNL Technical Report SRNL-STI-2012-00281, FCRD-SWF-2012-000116, 2012.

10. Brinkman, K., et al., Crystalline Ceramic Waste Forms: Report Detailing Data Collection in Support of Potential FY13 Pilot Scale Melter Test. Report SRNL Technical Report FCRD-SWF2012-000329, 2012.

11. Sobolev, I.A., et al., Comparative Study of Synroc-C Ceramics Produced by Hot-Pressing and Inductive Melting. Mater. Res. Soc. Symp. Proc., 1997. 465: p. 371.

12. Biagioni, C., P. Orlandi, and M. Pasero, Ankangite from the Monte Arsiccio mine (Apuan Alps, Tuscany, Italy): occurrence, crystal structure, and classification problems in cryptomelane group minerals. Periodico Di Mineralogia, 2009. 78(2): p. 3-11.

13. Carter, M.L., E.R. Vance, and H. Li, Hollandite-rich ceramic melts for the immobolisation of Cs. Mater. Res. Soc. Symp. Proc., 2003. 807: p. 249.

14. Aubin-Chevaldonnet, V., et al., Preparation and Characterization of $(\mathrm{Ba}, \mathrm{Cs})(\mathrm{M}, \mathrm{Ti})_{8} \mathrm{O}_{16}(\mathrm{M}=$ $\left.\mathrm{Al}^{3+}, \mathrm{Fe}^{3+}, \mathrm{Ga}^{3+}, \mathrm{Cr}^{3+}, \mathrm{Sc}^{3+}, \mathrm{Mg}^{2+}\right)$ Hollandite Ceramics Developed for Radioactive Cesium Immmobilization. Journal of Nuclear Materials, 2007. 366(1-2): p. 137-160.

15. Carter, M.L., E.R. Vance, and H. Li, Hollandite-rice Ceramic Melts for Immobilization of Cs. Mat. Res. Soc. Symp. Proc., 2004. 
16. Carter, M.L., et al., Mn Oxidation States in $B a_{x} C s_{y} M n_{z} T i_{8-z} O_{16}$. Mat. Res. Soc. Symp. Proc., 2004.

17. Whittle, K.R., et al., Structural Studies of Hollandite-Based Radioactive Waste Forms. Mat. Res. Soc. Symp. Proc., 2004. 807.

18. Buykx, W.J., et al., TITANATE CERAMICS FOR THE IMMOBILIZATION OF SODIUMBEARING HIGH-LEVEL NUCLEAR WASTE. Journal of the American Ceramic Society, 1988. 71(8): p. 678-688.

19. Potdar, H.S., et al., A simple chemical co-precipitation/calcination route for the synthesis of simulated synroc-B and synroc-C powders. Materials Chemistry and Physics, 2010. 123(2-3): p. 695-699.

20. Amoroso, J., et al., Single Phase Melt Processed Hollandite Waste Forms for Nuclear Waste Immobilization. Journal of Alloys and Compounds, 2013. submitted.

21. Billings, A.L., et al., Preliminary Study of Ceramics for Immobilization of Advanced Fuel Cycle Reprocessing Wastes. U.S. Department of Energy Report: FCRD-WAST-2010-000158, SRNLSTI-2010-00560, 2010. Savannah River National Laboratory, Aiken, SC.

22. Brinkman, K., K.M. Fox, and M. Tang, Development of Crystalline Ceramics for Immobilization of Advanced Fuel Cycle Reprocessing Wastes. U.S. Department of Energy Report: FCRD-SWF2011-000310, SRNL-STI-2011-00516, 2011. Savannah River National Laboratory, Aiken, SC.

23. Knyazev, O.A., S.V. Stefanovskii, and D.B. Lopukh, Determination of Melt Electric Resistivity at IMCC. Waste Management Conference, February 25-March 1, 2001 Tucson AZ, 2001. 